\title{
An Ultra-Short Dopamine Pathway Regulates Basal Ganglia Output
}

\author{
Fu-Wen Zhou, ${ }^{1}$ Ying Jin, ${ }^{1}$ Shannon G. Matta, ${ }^{1}$ Ming Xu, ${ }^{2}$ and Fu-Ming Zhou ${ }^{1}$ \\ ${ }^{1}$ Department of Pharmacology, University of Tennessee College of Medicine, Memphis, Tennessee 38163, and ${ }^{2}$ Department of Anesthesia and Critical Care, \\ University of Chicago, Chicago, Illinois 60637
}

\begin{abstract}
Substantia nigra pars reticulata $(\mathrm{SNr})$ is a key basal ganglia output nucleus critical for movement control. Its GABA-containing projection neurons intermingle with nigral dopamine (DA) neuron dendrites. Here we show that $\mathrm{SNr}_{\mathrm{GABA}}$ neurons coexpress dopamine $\mathrm{D}_{1}$ and $\mathrm{D}_{5}$ receptor mRNAs and also mRNA for TRPC3 channels. Dopamine induced an inward current in these neurons and increased their firing frequency. These effects were mimicked by $\mathrm{D}_{1}$-like agonists, blocked by a $\mathrm{D}_{1}$-like antagonist. $\mathrm{D}_{1}$-like receptor blockade reduced $\mathrm{SNr}$ GABA neuron firing frequency and increased their firing irregularity. These $\mathrm{D}_{1}$-like effects were absent in $\mathrm{D}_{1}$ or $\mathrm{D}_{5}$ receptor knock-out mice and inhibited by intracellularly applied $\mathrm{D}_{1}$ or $\mathrm{D}_{5}$ receptor antibody. These $\mathrm{D}_{1}$-like effects were also inhibited when the tonically active TRPC3 channels were inhibited by intracellularly applied TRPC3 channel antibody. Furthermore, stimulation of DA neurons induced a direct inward current in SNr GABA neurons that was sensitive to $\mathrm{D}_{1}$-like blockade. Manipulation of DA neuron activity and DA release and inhibition of dopamine reuptake affected SNr GABA neuron activity in a $\mathrm{D}_{1}$-like receptor-dependent manner. Together, our findings indicate that dendritically released dopamine tonically excites $\mathrm{SNr}$ GABA neurons via $\mathrm{D}_{1}-\mathrm{D}_{5}$ receptor coactivation that enhances constitutively active TRPC3 channels, forming an ultra-short substantia nigra pars compacta $\rightarrow$ SNr dopamine pathway that regulates the firing intensity and pattern of these basal ganglia output neurons.
\end{abstract}

\section{Introduction}

The substantia nigra is an important component of the basal ganglia (DeLong and Wichmann, 2007). It comprises two distinct parts: pars compacta $(\mathrm{SNc})$ and pars reticulata $(\mathrm{SNr})$. The major cell type in SNc is the dopamine (DA) neuron whose axon projects mainly to the striatum, forming the long-distance nigrostriatal DA pathway (Parent et al., 2000; Haber, 2003). SNr is populated primarily by a majority of GABA projection neurons and a minority of DA projection neurons (Fallon and Loughlin, 1995; Nelson et al., 1996; Parent et al., 2000). The GABA projection neurons fire spontaneous, mostly regular, high-frequency spikes (Hikosaka and Wurtz, 1983; Schultz, 1986).

$\mathrm{SNr}$ is a key output nucleus of the basal ganglia and inhibits its targets such as brainstem motor nuclei and thalamus (Hikosaka et al., 2000; McHaffie et al., 2005). It is critical to motor control, eye, and orofacial movements in particular. SNr neuronal activity is known to be influenced by the striatal and pallidal inputs that are themselves regulated by SNc-originated DA projection, thus forming the nigro-striato-nigral loop (Haber, 2003). Loss of SNc DA neurons in animal models of Parkinson's disease (PD) and

Received Sept. 15, 2008; revised July 9, 2009; accepted July 14, 2009.

This work was supported by a grant from the American Parkinson Disease Association and a Young Investigator Award from National Alliance for Research on Schizophrenia and Depression (F.-M.Z.) and National Institutes of Health Grants R01DA021194, R01MH067119, and R01NS058850 (F.-M.Z.), DA015525 (S.G.M.), and DA017323 and DA025088 (M.X.). We thank Dr. David Sibley for generously donating dopamine $D_{5}$ knock-out mice. We also thank Drs. Shengyuan Ding and Xingjun Wu for their help and Dr. Jonathan Jaggar for discussion.

Correspondence should be addressed to Fu-Ming Zhou, Department of Pharmacology, University of Tennessee College of Medicine, Memphis, TN 38163. E-mail: fzhou3@utmem.edu.

DOI:10.1523/JNEUROSCI.4402-08.2009

Copyright $\odot 2009$ Society for Neuroscience $\quad$ 0270-6474/09/2910424-12\$15.00/0 human PD patients often alters the firing frequency and/or pattern of the SNr neurons (Wichmann et al., 1999; Obeso et al., 2000; Nevet et al., 2004).

Evidence indicates that nigral DA cell somata and dendrites may release DA via vesicular exocytosis and/or reverse transport (Cheramy et al., 1981; Jaffe et al., 1998; Cragg et al., 2001; Falkenburger et al., 2001; Beckstead et al., 2004; Staal et al., 2004; Rice and Cragg, 2008). The $\mathrm{Ca}^{2+}$-dependent vesicular DA release from DA neuron dendrites may be triggered by pace-making activity-driven, L-type $\mathrm{Ca}^{2+}$ channel-mediated $\mathrm{Ca}^{2+}$ oscillation (Chan et al., 2007), potentially leading to a tonic extracellular DA level that is also regulated by reuptake (Cragg et al., 2001). Indeed, somatodendritically released DA has been indicated to induce a tonic autoinhibition of nigral DA neurons by activating the inhibitory $\mathrm{D}_{2}$ autoreceptors (Lacey et al., 1987; Pucak and Grace, 1994; Mercuri et al., 1997).

SNc DA neurons extend their dendrites deep into SNr (see Fig. 1A) (Björklund and Lindvall, 1975; González-Hernández and Rodríguez, 2000), in which tyrosine hydroxylase (TH)-positive DA dendrites and parvalbumin (PV)-positive GABA neurons intermingle closely. Such a proximity between DA dendrites and SNr GABA neurons may have important functional consequences because dendritically released DA may diffuse for a considerable distance as a result of the relatively low density of dopamine transporter (DAT) in SNr (Cragg et al., 2001).

These anatomical and physiological facts led to our hypothesis that dendritically released DA may directly activate DA receptors on SNr GABA output neurons, forming an ultra-short SNc $\rightarrow$ SNr DA pathway that provides a fast DA control over this key basal ganglia output nucleus. Because DA receptors do not di- 
rectly gate any ion channel, we further hypothesized that DA receptor activation may couple to and enhance TRPC3 channels, a type of cation channel that have been shown recently to be tonically active and regulate $\mathrm{SNr}$ GABA neuron activity (Zhou et al., 2008).

\section{Materials and Methods}

Mice. Wild-type 2- to 4-week-old male and female C57BL/6J mice were purchased from The Jackson Laboratory. $\mathrm{D}_{1}$ knock-out $(\mathrm{KO})$ mice and $\mathrm{D}_{5} \mathrm{KO}$ mice were generated, maintained, and genotyped according to established procedures (Xu et al., 1994; Hollon et al., 2002). All mice were housed in the animal facility on the campus of University of Tennessee Health Science Center (Memphis, TN).

Patch-clamp recording in midbrain slices. Coronal midbrain slices containing $\mathrm{SNc}$ and $\mathrm{SNr}$ were prepared according to well established procedures (Atherton and Bevan, 2005; Zhou et al., 2006, 2008). The cutting solution contained the following (in $\mathrm{mM}$ ): 220 sucrose, $2.5 \mathrm{KCl}, 1.25$ $\mathrm{NaH}_{2} \mathrm{PO}_{4}, 25 \mathrm{NaHCO}_{3}, 0.5 \mathrm{CaCl}_{2}, 7 \mathrm{MgCl}_{2}$, and $10 \mathrm{D}$-glucose. The slices were then transferred to a holding chamber containing the bathing solution (in mM): $125 \mathrm{NaCl}, 2.5 \mathrm{KCl}, 1.25 \mathrm{NaH}_{2} \mathrm{PO}_{4}, 25 \mathrm{NaHCO}_{3}, 2.5 \mathrm{CaCl}_{2}$, $1.3 \mathrm{MgCl}_{2}$, and $10 \mathrm{D}$-glucose. This bathing solution was also the normal perfusing solution. Drugs were applied via the bathing solution. The perfusion rate was $2 \mathrm{ml} / \mathrm{min}$ controlled by a peristaltic pump. Patch electrodes had resistances of 2-3 M $\Omega$ when filled with intracellular solution (in mM): $135 \mathrm{KCl}, 0.5$ EGTA, 10 HEPES, $2 \mathrm{Mg}$-ATP, and 0.2 $\mathrm{Na}_{3}$ GTP. pH was adjusted to 7.3 with $\mathrm{KOH}$. In a few cells, $125 \mathrm{~mm}$ $\mathrm{K}$-gluconate replaced $\mathrm{KCl}$ on an equal molar basis. For perforated patchclamp recording, $50 \mu \mathrm{g} / \mathrm{ml}$ gramicidin was added to the $\mathrm{KCl}$-based intracellular solution that led to perforated whole-cell mode 10-15 min after forming tight seal.

Recordings were made at $30^{\circ} \mathrm{C}$ under visual guidance of a video microscope (Olympus BX51W1) equipped with Nomarski optics and $60 \times$ water-immersion lens. We targeted large cells (likely to be GABA projection neurons) for recording and selected cells with action potentials overshooting at least $+20 \mathrm{mV}$ for analysis. Signals were recorded with Multiclamp 700B patch-clamp amplifiers, low-pass filtered at $5 \mathrm{kHz}$ by the built-in Bessel filter in the Multiclamp 700B amplifiers, digitized at $5-20 \mathrm{kHz}$, and analyzed with pClamp 9 program (Molecular Devices). For display and for reducing file size for the computer to handle, data (except action potentials) were digitally refiltered at 1 or $2 \mathrm{kHz}$ and resampled at lower sampling rates. Recordings with access resistance increase of $\geq 15 \%$ were rejected.

The summary data in Figures $2 B$ and $4 B$ were from two groups of selected neurons with stable baseline firing, good response to dopaminergic drugs, good recovery, and also matching temporal patterns in their response and recovery. A total of 21 neurons with significantly no-matching temporal patterns in their response and recovery were excluded to prevent the smearing-out of the response and recovery. The excluded cells had a response magnitude similar to that of included cells such that this exclusion did not affect our data or conclusion at all. Also, the recording of the initial several minutes was often not stable and thus was not included in analysis. The starting point of stable recording was defined as time $=0 \mathrm{~min}$.

Identification of substantia nigra pars reticulata GABA and DA neurons. Reliable and unambiguous identification of SNr GABA and DA neurons by their distinct electrophysiological characteristics has been described in detail in previous studies (Atherton and Bevan, 2005; Zhou et al., 2006; Lee and Tepper, 2007; Zhou et al., 2008).

Double immunostaining of GABA neurons and DA neurons. Under lethal anesthesia, mice were intracardially perfused with the ice-cold cutting solution described above and then $4 \%$ paraformaldehyde in $0.1 \mathrm{M}$ phosphate buffer $(\mathrm{PB})$. The removed brains were postfixed in the same fixative for $4 \mathrm{~h}$ at $4^{\circ} \mathrm{C}$ and then infused with $30 \%$ sucrose in $0.1 \mathrm{M} \mathrm{PB}, \mathrm{pH}$ 7.4, at $4^{\circ} \mathrm{C}$ over two nights. Coronal midbrain sections $(50 \mu \mathrm{m}$ in thickness) were cut on a Vibratome 1000 Plus. The sections then were processed for immunofluorescence detection of PV [a calcium-binding protein localized in GABA neurons but not in DA neurons in the $\mathrm{SNr}$ (González-Hernández and Rodríguez, 2000)] and TH (the rate limiting enzyme in DA biosynthesis). The free-floating sections were incubated with $2 \%$ fat-free milk, $1 \%$ bovine serum albumin (BSA), and $0.8 \%$ Triton $\mathrm{X}-100$ in $0.01 \mathrm{M}$ PBS for $1 \mathrm{~h}$ at room temperature to block nonspecific binding and permeate the cell membrane. After thorough rinsing, freefloating sections were incubated for $48 \mathrm{~h}$ at $4^{\circ} \mathrm{C}$ with the two primary antibodies (see below) and then rinsed in $0.01 \mathrm{~m}$ PBS three times for 10 min, followed by incubating with the two secondary antibodies (see below) for $2 \mathrm{~h}$ at room temperature in the dark. Both the primary and secondary antigen-antibody reactions occurred in $0.01 \mathrm{M}$ PBS containing $3 \%$ normal donkey serum, $1 \%$ BSA, and $0.8 \%$ Triton X-100. The two primary antibodies were a polyclonal TH antibody raised in sheep (diluted at 1:1000; Millipore Corporation) and a monoclonal PV antibody raised in mouse (diluted at 1:2000; Sigma). The two secondary antibodies were as follows: (1) donkey anti-sheep IgG antibody, conjugated with red Alexa Fluor 594 (diluted at 1:200; Invitrogen), used for labeling TH, and (2) donkey anti-mouse IgG antibody, conjugated with green fluorescent Alexa Fluor 488 (diluted at 1:200; Invitrogen), used for labeling PV. Detection of intracellularly infused $\mathrm{D}_{1}$ antibody was achieved by using an Alexa Fluor 594-tagged secondary antibody. An identical strategy was used in the study by Zhou et al. (2008).

Single-cell reverse transcription PCR. Our single-cell reverse transcription (scRT)-PCR procedures were described in detail by Zhou et al. (2008) and followed the principles and general methods of Surmeier et al. (1996). Patch pipettes were autoclaved to inactivate RNase. The intracellular solution (in mM: $135 \mathrm{KCl}, 0.5$ EGTA, $10 \mathrm{HEPES}$, and $1.5 \mathrm{MgCl}_{2}, \mathrm{pH}$ adjusted to 7.3) was prepared with RNase- and DNase-free water. Brief ( $\leq 5 \mathrm{~min}$ ) recording was done to provide electrophysiological fingerprints for SNr GABA and DA neurons. Once a stable and reliable recording was obtained, gentle suction was applied to aspirate the cytoplasm.

The aspirated cell content was expelled into a $0.2 \mathrm{ml}$ PCR tube, and potential genomic DNA was digested by DNase I (5 min at room temperature). Complete removal of genomic DNA was verified by RT-minus control in which no expected amplicon was detected when the reverse transcriptase was omitted, whereas all other reaction components were exactly the same. cDNA was synthesized using SuperScript III reverse transcriptase-based Cells-Direct cDNA Synthesis kit containing RNase inhibitor (Invitrogen). RT was performed at $50^{\circ} \mathrm{C}$ for $50 \mathrm{~min}$, yielding $30-35 \mu \mathrm{l}$ of cDNA solution. The reaction was terminated by heating to $85^{\circ} \mathrm{C}$ for $5 \mathrm{~min}$ and then chilling on ice. The $30-35 \mu \mathrm{l}$ of cDNA solution was used either immediately for PCR amplification or stored at $-80^{\circ} \mathrm{C}$ for later use. All steps ware performed according to the instructions of the manufacturer.

The cDNAs were amplified using a hot start, high specificity, and high yield Platinum PCR SuperMix (Invitrogen). To increase the detection probability of $\mathrm{D}_{1}$ and $\mathrm{D}_{5}$ mRNAs in a single neuron, the two-stage, nested PCR procedure was used, as detailed by Zhou et al. (2008).

To avoid potential interference among the primers, singleplex scRTPCR was used in the initial screening (Fig. $1 B$ ). In later experiments, to confirm the coexpression of multiple mRNAs in a single cell, the limited amount (30-35 $\mu \mathrm{l})$ of cDNA from a single neuron was divided, and separate PCR runs were performed to detect $\mathrm{D}_{1}, \mathrm{D}_{5}$, TRPC3, and glutamic acid decarboxylase 1 (GAD1) mRNAs in the same SNr GABA neurons (Fig. 1C).

PCR products from the second-stage PCR amplification were separated by $2 \%$ agarose gel electrophoresis and visualized by ethidium bromide under ultraviolet light. Then the bands on the gel were cut out, and the DNA fragments were extracted and purified with QiaQuick extraction kit (Qiagen) and sequenced. The obtained sequences were positively identified at http://blast.ncbi.nlm.nih.gov/Blast.cgi.

Primers were designed according to the sequences in GenBank (supplemental Table S1, available at www.jneurosci.org as supplemental material) and were accomplished using the web-based Primer3 software (Massachusetts Institute of Technology, Cambridge, MA). Whenever possible, intron-spanning primer pairs were used that help detect genomic DNA contamination. In cases in which negative scRT-PCR results were obtained, the effectiveness of the primer pairs was verified by whole-brain mRNAs that yielded positive products (supplemental Fig. S1, available at www.jneurosci.org as supplemental material). All primers were synthesized by Integrated DNA Technologies. 
To rule out contamination of extracellular debris that may contain mRNAs, the patch pipette was lowered into the tissue without actually aspirating cytoplasm, and then the pipette content was subjected to RT-PCR, yielding no product at all.

Chemicals. All chemicals, including D-2amino-5-phosphonopentanoic acid (D-AP-5), 6-cyano-7-nitroquinoxaline-2,3-dione (CNQX), and picrotoxin, were purchased from Sigma-Aldrich or Tocris Bioscience. Fresh DA solutions were used for each experiment.

Statistics. Descriptive statistics such as mean and SE were used. Paired $t$ test and Kolmogorov-Smirnov (K-S) test were also used to compare measurements in the same groups/cells when applicable. ANOVA was used for comparing the measurements obtained in two groups of mice. Linear regression analysis was used to analyze the linearity of the $I-V$ curves and determine the reversal potential. $p<0.05$ was considered to be significant.

\section{Results}

SNr GABA neurons express $D_{1}$ and $D_{5}$ receptor mRNAs

The first question we addressed was: do SNr GABA neurons express any DA receptors? We chose scRT-PCR to answer this question because of its high sensitivity and specificity (Surmeier et al., 1996). SNr GABA neurons in brain slices were identified by their characteristic fast spiking properties (Atherton and Bevan, 2005; Zhou et al., 2008). Then the cell content was aspirated into the recording patch pipette and expelled into a PCR tube. Reverse transcription was performed, followed by two-stage nested PCR (Zhou et al., 2008). Singleplex PCR was used to avoid potential interference among primers. We also used detection of GAD1 (a key GABA synthesis enzyme) mRNA as an indicator of successful cytoplasmic aspiration and reverse transcription. If GAD1 mRNA was not detected, indicating failure in cytoplasm aspiration and/or reverse transcription, no additional detection of DA receptor $m R N A s$ was pursued. Under these conditions, $D_{1}$ and $D_{5}$ mRNAs were detected in every GAD1 mRNA-positive SNr GABA neuron $(n=16)$ (Fig. $1 B)$, demonstrating that most, if not all, SNr GABA neurons express $\mathrm{D}_{1}$ and $\mathrm{D}_{5}$ mRNAs (Fig. $1 B$ ). In contrast, $\mathrm{D}_{2}, \mathrm{D}_{3}$, and $\mathrm{D}_{4}$ receptor mRNAs were not detected (for positive control for primer effectiveness, supplemental Fig. S1, available at www. jneurosci.org as supplemental material). The mRNA for the key enzyme for DA synthesis, TH, was not detected in any of these electrophysiologically identified SNr GABA neurons (data not shown). Furthermore, after dividing the limited amount (30-35 $\mu \mathrm{l}$ ) of cDNA from a single SNr GABA neuron, separate PCR runs detected $\mathrm{D}_{1}, \mathrm{D}_{5}, \mathrm{TRPC} 3$, and GAD1 mRNAs in the same single SNr GABA neurons $(n=5)$ (Fig. $1 C)$. These results indicate a coexpression of $D_{1}$ and $D_{5}$ receptors in $\mathrm{SNr}$ GABA neurons, pro-
A Dopamine dendrites intermingle with SNr GABA neurons

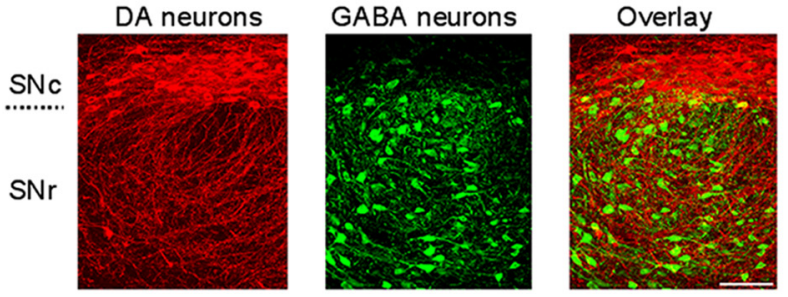

B GAD1 mRNA detection leads to detection of other mRNAs in single SNr neurons
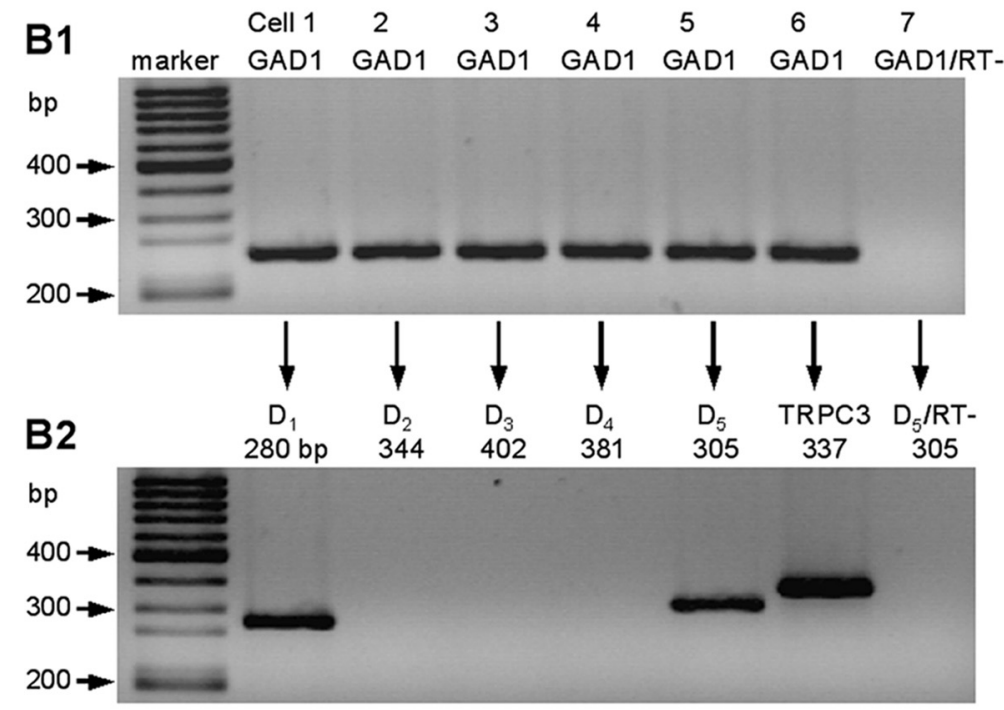

C Co-expression of $D_{1}, D_{5}, G A D 1$, and TRPC3 mRNAs in a single SNr neuron

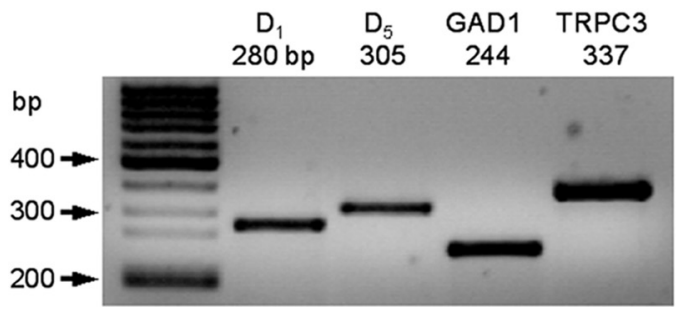

Figure 1. The $S N C$ DA dendrites intermingle with $S N r$ GABA neurons expressing $D_{1}$ and $D_{5}$ receptor and TRPC3 $m R N A s$. $A$, Confocal images of double-immunohistochemical staining for TH (red; a key enzyme for DA synthesis) and PV (green; expressed only in GABA neurons). Most TH-positive DA neurons are in $\mathrm{SNc}$ with their dendrites extending into $\mathrm{SNr}$, in which most neurons are the PV-positive GABA neurons. Scale bar, $100 \mu \mathrm{m}$. $\boldsymbol{B}$, To ensure maximal detection, singleplex scRT-PCR was used to detect GAD1 mRNA in electrophysiologically identified individual SNr GABA neurons (B1). Positive GAD1 mRNA detection indicated successful cell content aspiration and RT, providing the necessary condition for subsequent detection of DA receptor mRNAs from the same cell sample (B2). All amplicons were of expected sizes. No TH mRNA amplicon of $197 \mathrm{bp}$ was seen in GABA neurons, but it was detected in electrophysiologically identified DA neurons. $D_{5} / R T-$, RT-minus negative genomic DNA control for the intronless $D_{5}$ gene. $D_{2}, D_{3}$, and $D_{4}$ receptor mRNAs were not detected (for positive control for their primers, see supplemental Fig. $S 1$, available at www.jneurosci.org as supplemental material). C, After dividing the limited amount (30-35 $\mu$ l) of cDNA from a single neuron, separate $P C R$ runs detected $D_{1}, D_{5}, T R P C 3$, and GAD1 mRNAs in the same single SNr GABA neuron, confirming the coexpression of $D_{1}, D_{5}, G A D 1$, and TRPC3 mRNAs in these neurons.

viding a molecular substrate for dendritically released DA to directly influence these basal ganglia output neurons and also for a potential interaction between DA signaling and TRPC3 channel activity.

\section{Dopamine directly excites SNr GABA projection neuron firing}

If functional $D_{1}$ and $D_{5}$ receptors are indeed expressed in $\mathrm{SNr}$ GABA neurons, then DA should induce $\mathrm{D}_{1}$-like excitation as seen in other brain areas (Aosaki et al., 1998; Centonze et al., 2003). To detect potential direct $\mathrm{D}_{1}$-like excitation in $\mathrm{SNr}$ GABA neurons, 
A
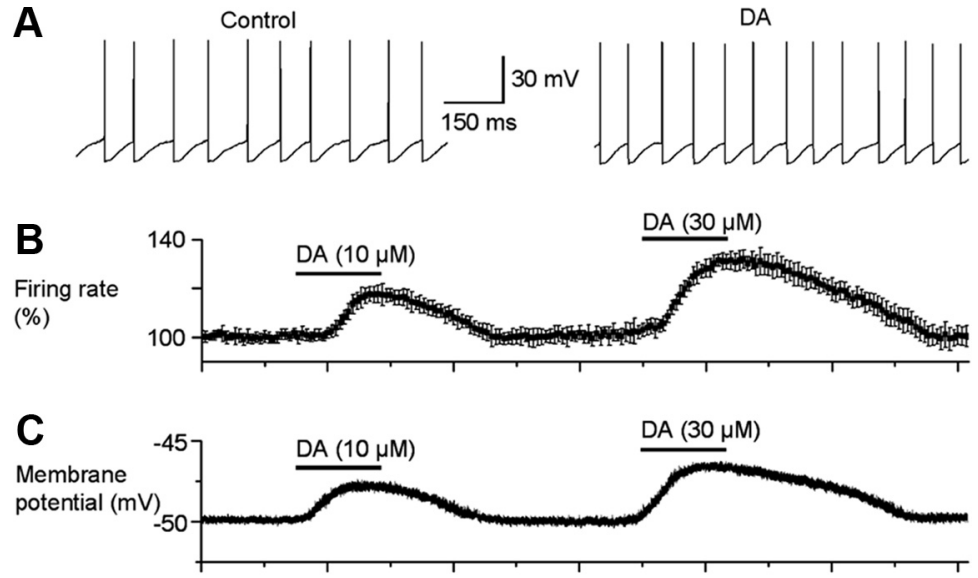

D

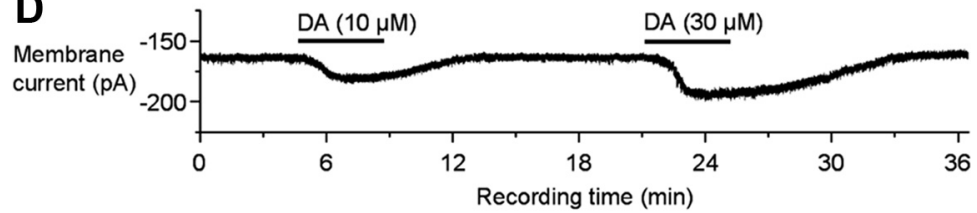

E

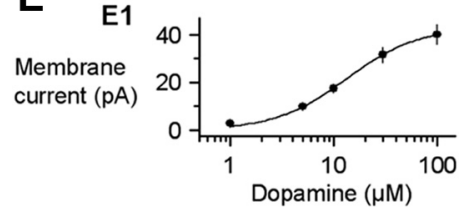

E2
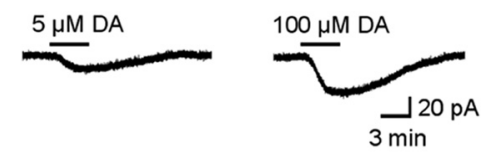

E3

$100 \mu \mathrm{M} D A$

Figure 2. DA directly excited SNr GABA projection neurons. All recordings were made in the presence of picrotoxin, D-AP-5, and CNQX to block fast synaptic transmission. Sulpiride was present to prevent potential complications from $D_{2}$ autoinhibition of $D A$ neurons. $A$, Examples of spontaneous spikes under control conditions (left) and during $10 \mu \mathrm{m} \mathrm{DA}$ application (right). $\boldsymbol{B}$, Group data of DA enhancement of spiking. The firing enhancement, measured over the 2 min peak enhancement period, was $16.2 \pm 1.9$ and $31.0 \pm 2.1 \%$ for 10 and $30 \mu \mathrm{m}$ DA, respectively. $n=14$. C, An example recording showing that, after blocking spikes with $1 \mu \mathrm{M}$ TTX, DA induced a clear depolarization. D, An example recording showing that, when voltage clamped at $-70 \mathrm{mV}$, DA induced a clear inward current in the presence of $1 \mu \mathrm{M}$ TTX. Note that SNr GABA neurons are normally depolarized and have a large holding current when clamped at $-70 \mathrm{mV}$ (Zhou et al., 2008). E, E1 shows the dose-response relationship of DA-induced inward current. The curve is from Hill equation fitting: $E C_{50}$ was $13.3 \pm 0.7 \mu \mathrm{m}$ and Hill slope of $1.2 \pm 0.1 . n=5-9$ for each data point. $E 2$ and $E 3$ are example inward currents induced by 5 and $100 \mu \mathrm{m} \mathrm{DA}$, respectively, in an SNr GABA neuron voltage clamped at $-70 \mathrm{mV}$.

A $\mathrm{DA}(30 \mu \mathrm{M})$

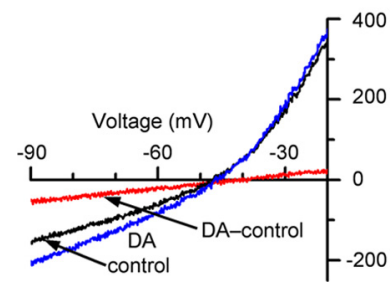

B D1-ike agonist SKF81297 (5 $\mathrm{\mu M}$ )

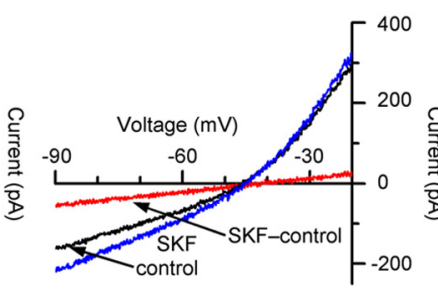

Figure 3. $D A$ or a $D_{1}$-like agonist induced a linear, voltage-independent inward current in $\mathrm{SNr}$ GABA projection neurons. $\boldsymbol{A}$, Voltage ramp reveals the $I-V$ relationship of DA-induced current. The ramp was between -90 and $-20 \mathrm{mV}$. The $30 \mu \mathrm{m}$ DA-induced net current (red trace) was obtained by subtracting the current generated under control conditions (black trace) from the current generated during DA application (blue trace). In other words, the red, net current trace $=$ the blue DA trace - the black control trace. Linear regression analysis indicated a reversal potential at approximately $-37 \mathrm{mV}$. $\boldsymbol{B}$, The same voltage ramp protocol revealed that $5 \mu \mathrm{M}$ SKF81297 (SKF) induced a similar linear current with a reversal potential also at approximately $-37 \mathrm{mV}$. Identical subtraction procedure was performed. All traces were individual traces.

we first blocked glutamate- and GABA-mediated fast synaptic transmission with $20 \mu \mathrm{M}$ D-AP-5, $10 \mu \mathrm{M}$ CNQX, and $100 \mu \mathrm{M}$ picrotoxin to remove complications of synaptic activity. Under this condition, bath application of 10 and $30 \mu \mathrm{M}$ DA reliably increased the firing rate of $\mathrm{SNr}$ GABA neurons by $16.2 \pm 1.9$ and $31.0 \pm 2.1 \%$ from a baseline frequency of $10.7 \pm 0.9$ $\mathrm{Hz}$, respectively (measured over the 2-min peak enhancement period; $p<$ $0.01 ; n=14)$ (Fig. 2A,B).

The question now was: how did DA induce this excitation? We found that DA did not affect action potential shape and, after adjusting membrane potential to the pre-DA level with hyperpolarizing current, it also did not alter the fast afterhyperpolarization (AHP) nor medium AHP. These results indicate that DA enhanced SNr GABA neuron firing without detectable effect on voltage-gated $\mathrm{Na}^{+}$and $\mathrm{K}^{+}$ channels or $\mathrm{Ca}^{2+}$-activated $\mathrm{K}^{+}$channels responsible for action potential generation and repolarization and the AHPs. Therefore, other mechanisms must be involved. We hypothesized that the primary mechanism of DA excitation could be a $\mathrm{DA}$-induced direct depolarization in $\mathrm{SNr}$ GABA neurons.

To characterize the DA-induced depolarization, action potentials were blocked with $1 \mu \mathrm{M}$ tetrodotoxin (TTX) to obtain stable membrane potential in SNr GABA neurons (Fig. 2C). Under this condition, bath application of 10 and $30 \mu \mathrm{M} \mathrm{DA}$ induced a clear depolarization of $1.8 \pm 0.1$ and $2.7 \pm 0.2 \mathrm{mV}$ from a baseline membrane potential of $-49.3 \pm 1.3 \mathrm{mV}$, respectively $(n=9)$ (Fig. 2C). These DA-induced direct depolarization amplitudes are similar to those in striatal cholinergic interneurons (Centonze et al., 2003) and medium spiny neurons (Yasumoto et al., 2002). Because SNr GABA neurons have a depolarized membrane potential close to the spike threshold, even a modest depolarization will affect neuronal firing and circuitry operation, conferring physiological significance onto this direct DA effect.

To further test our hypothesis, SNr GABA neurons were voltage clamped at $-70 \mathrm{mV}$. At this holding potential, bath application of 10 and $30 \mu \mathrm{M}$ DA induced an inward current of $17.4 \pm 1.7$ and $31.3 \pm 2.9 \mathrm{pA}$ from a baseline membrane current of $-160.1 \pm 16.5 \mathrm{pA}$, respectively $(n=9)$ (Fig. $2 D)$ [much of the baseline holding current was attributable to the tonic TRPC3 current (Zhou et al., 2008)]. Hill equation fitting indicated an $\mathrm{EC}_{50}$ of $13.3 \pm 0.7 \mu \mathrm{M}$ with a Hill slope of $1.2 \pm 0.1$ (Fig. $2 E$ ). Whole-cell conductance, monitored with $-10 \mathrm{mV}, 100 \mathrm{~ms}$ voltage pulses, was increased from $5.28 \pm 0.41 \mathrm{nS}$ under control conditions to $6.55 \pm 0.66 \mathrm{nS}$ during $30 \mu \mathrm{M} \mathrm{DA}$ application $(n=$ $8 ; p<0.05$ ), suggesting an opening or enhancement of ion channels that mediate an inward current at $-70 \mathrm{mV}$. All these DA-evoked effects were prevented by $5 \mu \mathrm{M} \mathrm{D} \mathrm{D}_{1}$-like antagonist SKF83566 (8-bromo-2,3,4,5-tetrahydro-3-methyl-5-phenyl-1 $\mathrm{H}$-3benzazepin-7-ol hydrobromide) (supplemental Fig. S2, available at www.jneurosci.org as supplemental material). A similar inward current was induced by $30 \mu \mathrm{m} \mathrm{DA}$ in SNr GABA neurons voltage clamped at $-70 \mathrm{mV}$ under conventional whole-cell recording mode with K-gluconate-based intracellular solution 
(32.5 $\pm 4.4 \mathrm{pA} ; n=4)$ and under gramicidin-perforated recording configuration $(29.7 \pm 4.7 \mathrm{pA} ; n=3)$.

Next, a voltage-ramp protocol was used to determine the $I-V$ relationship of the DA-induced current. The linear ramp was between -90 and $-20 \mathrm{mV}$. After obtaining a stable baseline recording, the ramp protocol was activated and $30 \mu \mathrm{M}$ DA was bath applied. The net DA-induced current was obtained by subtracting the current generated under control condition from the current generated during DA application (Fig. $3 A$ ). Linear regression analysis indicated that the DA current $I-V$ was linear between -90 and $-20 \mathrm{mV}$ with a reversal potential of $-37.3 \pm 1.3 \mathrm{mV}(n=5)$, suggesting a tonically active, mixed cation channel. It was not $I_{\mathrm{h}}$ because $I_{\mathrm{h}}$ has a voltagedependent activation with a threshold at $-60 \mathrm{mV}$ or more negative (Harris and Constanti, 1995). In SNr GABA neurons, $I_{\mathrm{h}}$ is very small. Furthermore, the DA current $I-V$ curve in the presence of ZD7288 (4-ethylphenylamino-1,2-dimethyl-6methylaminopyrimidinium chloride), a selective $I_{\mathrm{h}}$ blocker (Harris and Constanti, 1995), was similar to that obtained without ZD7288. As will be discussed below (see Fig. 6), this current was likely mediated by TRPC3 channels that are tonically active cation channels in SNr GABA neurons (Zhou et al., 2008).
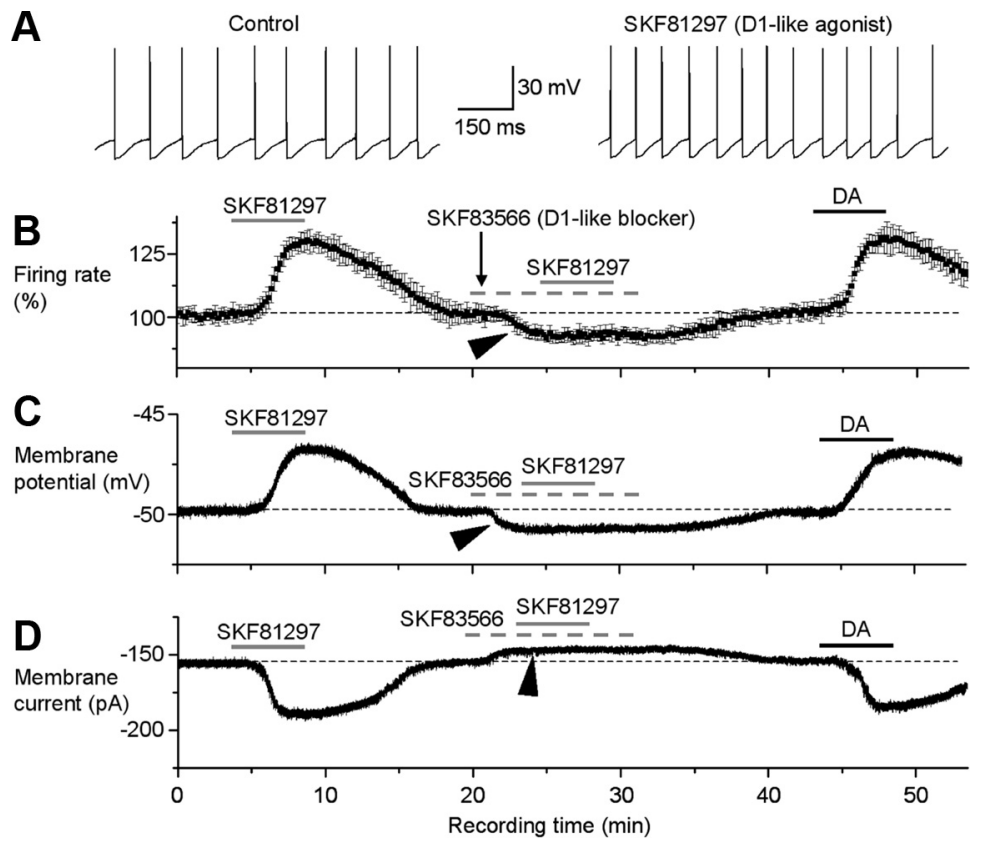

Figure 4. $\quad D_{1}$-like agonist SKF81297 mimicked DA effects in SNr GABA projection neurons that were prevented by the $D_{1}$-like blocker SKF83566. All recordings were made in the presence of picrotoxin, D-AP-5 and CNQX to block fast synaptic transmission. $\boldsymbol{A}$, Examples of spontaneous spikes under control (left) and during $5 \mu \mathrm{M}$ SKF81297 application (right). $\boldsymbol{B}$, Group data showing SKF81297 enhancement of firing and the recovery of the effect. The SKF81297-induced firing enhancement was $29.6 \pm 2.5 \%$, measured over the 2 min peak enhancement period. $n=9$. The $D_{1}$-like excitatory effect was prevented by the $D_{1}$-like antagonist SKF83566. Note that SKF83566 induced an inhibition indicated by the arrowhead, suggesting an endogenous tonic $D_{1}$-like activity that will be discussed later. At the end of the recording, $30 \mu \mathrm{m} \mathrm{DA}$ was applied to show that the neuron was still healthy. $C, D$, Example recordings showing that, after blocking spikes with $1 \mu \mathrm{M}$ TTX, SKF81297 induced a clear depolarization in current-clamp recording mode $(\boldsymbol{C})$ and a clear inward current when voltage clamped at $-70 \mathrm{mV}(\boldsymbol{D})$. This depolarization or inward current was prevented by the $\mathrm{D}_{1}$-like antagonist SKF83566 $(5 \mu \mathrm{m})$. Also note that SKF83566 itself induced a hyperpolarization or outward current (arrowhead in $C, D$ ), suggesting an endogenous tonic $\mathrm{D}_{1}$-like activity (addressed later).

\section{$D_{1}$-like receptor agonists mimicked and an antagonist blocked $\mathrm{D}_{1}$-like effects in SNr GABA neurons}

Based on the results described above, we reasoned that $D_{1}$ and/or $\mathrm{D}_{5}$ receptors were mediating the direct excitation of $\mathrm{DA}$ in $\mathrm{SNr}$ GABA neurons. If this hypothesis was correct, then $\mathrm{D}_{1}$-like agonists should mimic the effects of DA. To test this reasoning, we investigated the effects of SKF81297 (6-chloro-2,3,4,5-tetrahydro-1-phenyl-1 H-3-benzazepine hydrobromide) and dihydrexidine, two selective, full agonists for $\mathrm{D}_{1}$-like receptors (Lovenberg et al., 1989; Aosaki et al., 1998). After a stable baseline recording, bath application of $5 \mu \mathrm{M}$ SKF81297 had a clear excitatory effect on SNr GABA neurons (Fig. 4), similar to that induced by $30 \mu \mathrm{M}$ DA (Fig. 2). The spontaneous spike firing rate was increased by $29.6 \pm 2.5 \%$ during SKF81297 application $(n=9 ; p<0.01)$ (Fig. $4 A, B)$. This effect was prevented by $5 \mu \mathrm{M} \mathrm{D}_{1}$-like blocker SKF83566 (Fig. $4 B$ ), clearly indicating an involvement of $D_{1}$ like receptors.

To further characterize the depolarization that accompanied the SKF81297-induced increase in SNr GABA neuron firing rate, action potentials were blocked with $1 \mu \mathrm{M}$ TTX such that changes in membrane potential could be reliably detected. Under these conditions, bath application of $5 \mu \mathrm{M}$ SKF81297 induced a clear depolarization of $2.6 \pm 0.2 \mathrm{mV}(n=9)$, and this effect was prevented by $5 \mu \mathrm{M} \mathrm{D}_{1}$-like antagonist SKF83566 (Fig. 4C).

When the SNr GABA neurons were voltage clamped at $-70 \mathrm{mV}$, $5 \mu \mathrm{M}$ SKF81297 induced an inward current of $30.8 \pm 3.8 \mathrm{pA}(n=$
8) (Fig. 4D), and whole-cell conductance was increased to $6.22 \pm$ $0.34 \mathrm{nS}$ from $5.12 \pm 0.40 \mathrm{nS}$ under control condition $(n=6)$, indicating an opening of ion channels. These effects were prevented by $5 \mu \mathrm{M}$ SKF83566 (Fig. 4D). Furthermore, in the presence of $1 \mu \mathrm{M}$ TTX, voltage ramp experiments showed that the SKF81297-induced current was linear between -90 and -20 $\mathrm{mV}$ with a reversal potential of $-37.5 \pm 1.5 \mathrm{mV}(n=4)$ (Fig. $3 B)$. These characteristics were identical to those of the DAinduced current (Fig. 3A).

Similar current-clamp and voltage-clamp results were obtained with a second $\mathrm{D}_{1}$-like agonist, dihydrexidine, that is molecularly distinct from the phenylbenzazepines such as SKF81297 (Lovenberg et al., 1989).

Together, these data indicate that $\mathrm{D}_{1}$-like agonists mimic, and a $\mathrm{D}_{1}$-like antagonist blocks, DA-induced effects in SNr GABA neurons, supporting our idea that $\mathrm{D}_{1}$ and/or $\mathrm{D}_{5}$ receptor activation may directly depolarize these basal ganglia output neurons.

In contrast, in the presence of $5 \mu \mathrm{M} \mathrm{D}$-like antagonist SKF83566, neither $\mathrm{D}_{2}$-like receptor agonist quinpirole (Lacey et al., 1987; Mercuri et al., 1997) (1-10 $\mu \mathrm{M})$ nor $\mathrm{D}_{2}$-like receptor antagonist sulpiride $(1 \mu \mathrm{M})$ affected the firing rate, membrane potential, or membrane current in SNr GABA neurons $(n=2-3$; data not shown). These results were consistent with our scRTPCR data showing a lack of $D_{2}, D_{3}$, and $D_{4}$ mRNA in SNr GABA neurons. Quinpirole and sulpiride had typical effects in SNc and SNr DA neurons $(n=3-6)$ as reported in the literature (Lacey et al., 1987). 


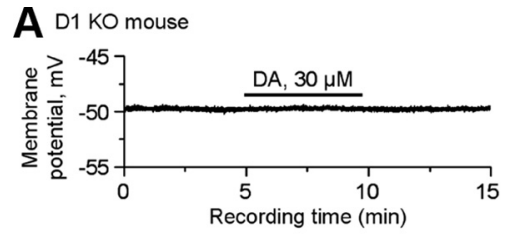

C intracellular D1 antibody infusion, WT

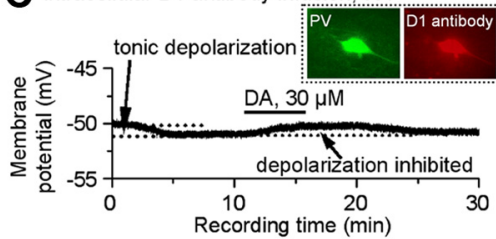

E intracellular D5 antibody infusion, WT

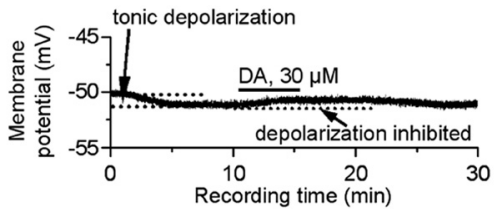

G intracellular D1 antibody infusion, D1 ko

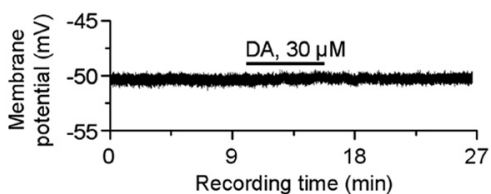

B D5 KO mouse

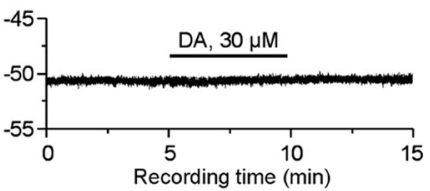

D D1 antigenic peptide blocks D1 antibody effects, WT

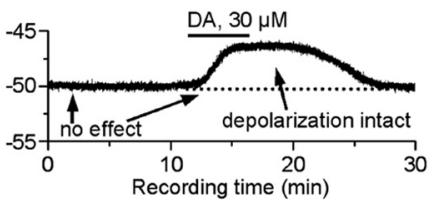

F D5 antigenic peptide blocks D5 antibody effects, WT

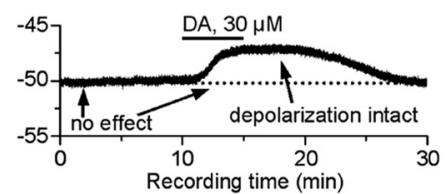

H intracellular D5 antibody infusion, D5 KO

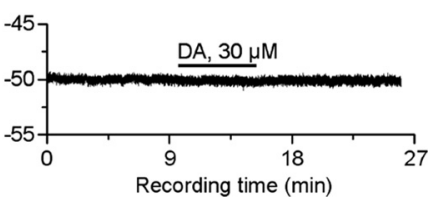

Figure 5. Both $D_{1}$ and $D_{5}$ receptors are needed for $D_{1}$-like excitation in SNr GABA neurons. $A, B$, Exogenous $30 \mu \mathrm{m}$ DA was without effect on the membrane potential in $\mathrm{SNr} G A B A$ neurons in both $D_{1} \mathrm{KO}$ mice $(\boldsymbol{A})$ and $\mathrm{D}_{5} \mathrm{KO}$ mice $(\boldsymbol{B})$. $\boldsymbol{C}, \boldsymbol{D}$, In wild-type mice, intracellular infusion of $D_{1}$ receptor antibody caused a small but clear hyperpolarization, indicating a tonic $D_{1}$-dependent depolarization. Once infused with $\mathrm{D}_{1}$ antibody, the DA-induced depolarization was greatly inhibited ( $\boldsymbol{C}$ ). Inset, Conventional fluorescence pictures of immunostaining detection of $D_{1}$ antibody infused into a PV-positive $S N r G A B A$ neuron. In contrast, intracellular infusion of a mixture of $D_{1}$ antibody and its antigen peptide had no effect by itself and did not inhibit the DA response (D). $\boldsymbol{E}, \boldsymbol{F}$, Similarly, in wild-type mice, intracellular infusion of $D_{5}$ receptor antibody caused a hyperpolarization $(0.6 \pm 0.1 \mathrm{mV} ; n=5)$, indicating a tonic $\mathrm{D}_{5}$-dependent depolarization. Once infused with $\mathrm{D}_{5}$ antibody, $30 \mu \mathrm{m} \mathrm{DA}$ only induced a depolarization of $0.6 \pm 0.1(\boldsymbol{E})$. Intracellular infusion of a mixture of $D_{5}$ antibody and its antigen peptide had no effect by itself and did not inhibit the DA response with 30 $\mu \mathrm{M}$ DA inducing a depolarization of $2.5 \pm 0.4 \mathrm{mV}(\boldsymbol{F})$. Comparable voltage-clamp data were also obtained. $\boldsymbol{G}, \boldsymbol{H}$, Intracellular infusion of $D_{1}$ receptor antibody into $S N r G A B A$ neurons in $D_{1} K 0$ mice had no effect $(\boldsymbol{G})$. Similarly, infusion of $D_{5}$ receptor antibody into $\mathrm{SNr}$ GABA neurons in $\mathrm{D}_{5} \mathrm{KO}$ mice also had no effect $(\boldsymbol{H})$. All traces were individual traces.

\section{Absence of $D_{1}$-like DA effects in SNr GABA neurons in $D_{1}$ or $\mathrm{D}_{5}$ receptor $\mathrm{KO}$ mice}

$D_{1}$ and $D_{5}$ receptors are known to induce similar effects (Neve et al., 2004), and SNr GABA neurons express both $\mathrm{D}_{1}$ and $\mathrm{D}_{5}$ receptor mRNAs (Fig. $1 B, C$ ). Thus, the $\mathrm{D}_{1}$-like effects described above may be mediated by $D_{1}$ and/or $D_{5}$ receptors. There is currently no ligand selective for $\mathrm{D}_{1}$ or $\mathrm{D}_{5}$ receptors. To overcome this difficulty, we used $\mathrm{D}_{1}$ receptor $\mathrm{KO}$ mice and $\mathrm{D}_{5} \mathrm{KO}$ mice (Xu et al., 1994; Hollon et al., 2002).

In contrast to wild-type mice, in SNr GABA neurons from $\mathrm{D}_{1}$ $\mathrm{KO}$ mice, $30 \mu \mathrm{M}$ DA had no significant effect on the spontaneous firing rate $(9.9 \pm 0.8 \mathrm{~Hz}$ under control vs $9.7 \pm 0.8 \mathrm{~Hz}$ during DA; $p>0.05 ; n=5)$. In the presence of $1 \mu \mathrm{M}$ TTX, $30 \mu \mathrm{M}$ DA had no significant effect on the membrane potential $(n=4)$ (Fig. $5 A)$ or membrane current ( $n=5$; data not shown) in SNr GABA neurons from $\mathrm{D}_{1} \mathrm{KO}$ mice. SNr GABA neurons $(n=5)$ from wildtype littermates showed the same $D_{1}$-like DA responses as in wild-type mice described previously. Similar to $\mathrm{D}_{1} \mathrm{KO}$ mice, in SNr GABA neurons from $\mathrm{D}_{5} \mathrm{KO}$ mice, $30 \mu \mathrm{M}$ DA did not affect the spontaneous firing rate $(9.6 \pm 0.7 \mathrm{~Hz}$ under control vs $9.5 \pm$ $0.7 \mathrm{~Hz}$ during DA; $p>0.05 ; n=4)$, membrane potential $(n=4)$ (Fig. $5 B)$, or membrane current $(n=5)$.
Also, in these same $\mathrm{D}_{1} \mathrm{KO}$ mice and $\mathrm{D}_{5}$ KO mice, SNc DA neurons $(n=4-6)$ and SNr DA neurons $(n=3-4)$ displayed the typical $\mathrm{D}_{2}$ receptor-mediated autoinhibition when $30 \mu \mathrm{M}$ DA was bath applied, indicating that the lack of $\mathrm{D}_{1}$-like responses in SNr GABA neurons in these mutant mice was not attributable to unhealthy brain slices.

In aggregate, these results indicate an involvement of an apparent $D_{1}$ and $D_{5}$ receptor coactivation, i.e., both $\mathrm{D}_{1}$ and $\mathrm{D}_{5}$ receptors is required for the $D_{1}$-like responses.

\section{$D_{1}$ or $D_{5}$ receptor antibody inhibited the $\mathrm{D}_{1}$-like effects in SNr GABA neurons}

To provide additional evidence from a different approach for the $\mathrm{D}_{1}$ and $\mathrm{D}_{5}$ receptor coactivation indicated by $\mathrm{D}_{1}$ and $\mathrm{D}_{5}$ receptor knock-out mice, we used $\mathrm{D}_{1}$ and $\mathrm{D}_{5}$ receptor antibodies against an intracellular domain of the receptor proteins and applied these antibodies intracellularly via the patch pipette. Intracellular infusion of proteins (enzymes and antibodies) is a well established technique (Tauc, 1980; Aragay et al., 1995). The antibody binds to and may thus interfere with the functioning of the corresponding receptor. This strategy has been used to identify receptor subtypes when subtypespecific ligands are not available (Amaral and Pozzo-Miller, 2007; Zhao et al., 2008; Zhou et al., 2008) (Dr. Jonathan Jaggar, personal communication). The antibodies, purchased from Santa Cruz Biotechnology, were diluted at 1:100 in intracellular pipette solution. We found that intracellular application of $\mathrm{D}_{1}$ receptor antibody caused a clear hyperpolarization in current clamp $(0.6 \pm 0.1 \mathrm{mV} ; n=5)$ (Fig. $5 C$ ). Effective infusion of the antibody into the recorded neuron was confirmed by immunohistochemical detection (Fig. 5C, inset). More importantly, in cells infused with $\mathrm{D}_{1}$ receptor antibody, $30 \mu \mathrm{M} \mathrm{DA}$ induced a depolarization of only $0.6 \pm 0.1 \mathrm{mV}(n=5)$ (Fig. $5 C)$, a $78 \%$ inhibition compared with that under control condition shown in Figure $2 C$. When voltage clamped at $-70 \mathrm{mV}$, similar results that mirror the current-clamp data were obtained (data not shown). In contrast, a mixture of $D_{1}$ receptor antibody and its antigenic peptide (at a weight ratio of $1: 1$ or 1:2) had no effect by itself and did not inhibit the $30 \mu \mathrm{M} \mathrm{DA}$-induced depolarization $(2.7 \pm 0.4 \mathrm{mV} ; n=$ 3) (Fig. $5 D)$. Thus, the effects of $\mathrm{D}_{1}$ receptor antibody were specific.

Intracellularly applied $\mathrm{D}_{5}$ antibody had effects similar to those of $\mathrm{D}_{1}$ receptor antibody $(n=5)$ (Fig. $\left.5 E, F\right)$. Furthermore, $\mathrm{D}_{5}$ receptor antigen peptide did not neutralize the effects of the $D_{1}$ antibody $(n=2)$, and $\mathrm{D}_{1}$ antigen peptide did not neutralize the effects of the $\mathrm{D}_{5}$ antibody $(n=2)$, also indicating that the effects of $\mathrm{D}_{1}$ and $\mathrm{D}_{5}$ antibodies were specific. As shown in Figure 5, $C$ and $E$, intracellularly applied $\mathrm{D}_{1}$ or $\mathrm{D}_{5}$ antibody, respectively, also induced a hyperpolarization, indicating a tonic $\mathrm{D}_{1}$ and $\mathrm{D}_{5}$ receptor- 
A TRPC3 channels ultimately mediate D1-like responses

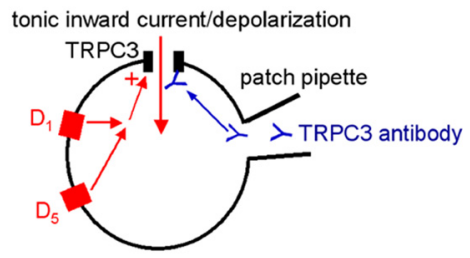

B Intracellular infusion of TRPC3 antibody

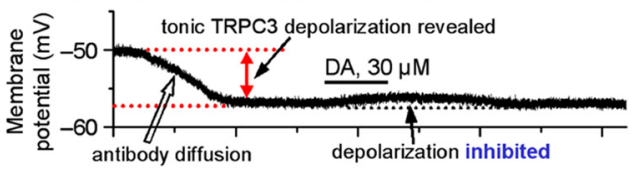

C Mix of TRPC3 antibody \& antigen peptide has no effect: antibody effects are specific

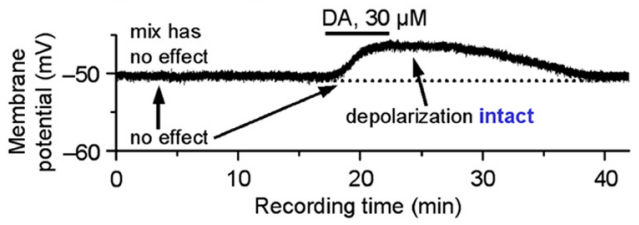

Figure 6. TRPC 3 channels are the likely effector of $D_{1}-D_{5}$ receptor coactivation in $S N r G A B A$ neurons. $A$, Diagrammatic representation of the hypothesized $D_{1}-D_{5}$ receptor coactivation coupled to TRPC3 channels that may be inhibited by intracellularly infused TRPC3 antibody. $\boldsymbol{B}$, Intracellular infusion of TRPC3 channel antibody revealed a tonic depolarization. Once infused with TRPC3 antibody, the DA-induced depolarization was greatly reduced. The open arrow points to the gradual process by which TRPC3 antibody exerts its effect. C, Premixing of TRPC3 antibody with TRPC 3 antigenic peptide neutralized TRPC 3 antibody's effects (compare with $\boldsymbol{B}$ ), indicating that TRPC 3 antibody effects were specific. Comparable voltage-clamp data were also obtained. The traces in $\boldsymbol{B}$ and $\boldsymbol{C}$ were individual traces.

dependent depolarization that was inhibited by either one of these two antibodies. Finally, none of these antibody-induced effects was seen in SNr GABA neurons in $\mathrm{D}_{1} \mathrm{KO}$ mice $(n=3)$ and $\mathrm{D}_{5} \mathrm{KO}$ mice $(n=3)$ (Fig. $\left.5 G, H\right)$.

Together, our data clearly suggest that an apparent coactivation of $D_{1}$ and $D_{5}$ receptors was required to cause an inward current or depolarization in SNr GABA neurons. Inhibition of one of these two receptors led to the inhibition of the entire $\mathrm{D}_{1}$-like excitation.

Next we turned to this question: because $D_{1}$ and $D_{5}$ receptors do not directly gate any ion channel, what effector ion channel mediates the $\mathrm{D}_{1}$-like excitation? The experiments below were designed to identify the effector ion channel(s).

\section{TRPC3 channels mediate the $\mathrm{D}_{1}$-like effects in $\mathrm{SNr}$ \\ GABA neurons}

Our data presented in Figure 3 indicate that the DA current $I-V$ curve was linear between -90 and $-20 \mathrm{mV}$ with a reversal potential at approximately $-37 \mathrm{mV}$, suggesting a constitutively active, mixed cation channel, similar to the $I-V$ relationship of the TRPC3 channel-mediated current in SNr GABA neurons (Zhou et al., 2008). Our scRT-PCR data also showed that $D_{1}, D_{5}$, and TRPC3 mRNAs were coexpressed in the same SNr GABA neurons (Fig. 1C). Together, these data indicate that the apparent $\mathrm{D}_{1}-\mathrm{D}_{5}$ receptor coactivation opened a type of depolarizing cation channels, consistent with the idea that DA may enhance the tonically active TRPC 3 channels. To test this hypothesis, we investigated whether blocking TRPC 3 channels also blocked the $\mathrm{D}_{1}$-like excitation (Fig. 6A).

Because of the lack of selective agonists and antagonists, we applied a TRPC3 antibody intracellularly via the recording pi-

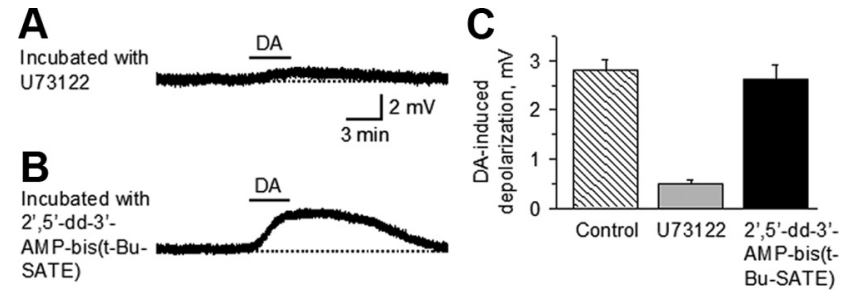

Figure 7. Inhibition of PLC, but not adenylyl cyclase, causes a substantial inhibition of the DA response. $A$, In SNr GABA neurons from slices incubated for at least 20 min with a PLC inhibitor U73122 $(5 \mu \mathrm{M}), 30 \mu \mathrm{m}$ DA induced a depolarization of $0.5 \pm 0.1 \mathrm{mV}(n=9)$ from their resting potential at around $-50 \mathrm{mV}$ in the presence of $1 \mu \mathrm{m}$ TTX. $B$, In SNr GABA neurons from slices incubated for at least 20 min with an adenylyl cyclase inhibitor $2^{\prime}, 5^{\prime}$-dd-3'-AMP-bis(t-BuSATE) $(5 \mu \mathrm{m}), 30 \mu \mathrm{m}$ DA induced a depolarization of $2.6 \pm 0.3 \mathrm{mV}(n=8)$ from their resting potential at approximately $-50 \mathrm{mV}$ in the presence of $1 \mu \mathrm{M}$ TTX. C, Summary graph showing the $30 \mu \mathrm{M}$ DA-induced depolarization under control condition and after incubation with U73122 or 2', $5^{\prime}$-dd-3'-AMP-bis(t-Bu-SATE). The depolarization in U73122-treated cells was significantly smaller than other two groups $(p<0.01)$, whereas there was no significant difference between control and treatment with 2', $5^{\prime}$-dd-3'-AMP-bis(t-Bu-SATE).

pette as illustrated in Figure 6A. The TRPC3 antibody (purchased from Alomone Labs) is known to interfere with or inhibit the functioning of TRPC3 channels (Albert et al., 2006; Amaral and Pozzo-Miller, 2007; Zhou et al., 2008). Intracellular infusion of this antibody (diluted at 1:100 in the pipette solution) caused a hyperpolarization of $6.9 \pm 0.6 \mathrm{mV}(n=6)$, probably by inhibiting the tonic TRPC3-mediated depolarization (Fig. $6 B$, open arrow) (Amaral and Pozzo-Miller, 2007; Zhou et al., 2008). In these TRPC3 antibody-infused cells, the DA-induced depolarization was substantially inhibited with the residual amplitude being only $0.6 \pm 0.1 \mathrm{mV}(n=6)$ (Fig. $6 B)$. The effects of TRPC3 antibody were neutralized by its antigenic peptide (antibody/ peptide ratio was $1: 1$ or 1:2 by weight) with an intact $30 \mathrm{DA}$ $\mu \mathrm{M}$-induced depolarization $(2.8 \pm 0.4 \mathrm{mV} ; n=3$ ) (Fig. $6 \mathrm{C}$ ), indicating that the inhibitory effects of TRPC 3 antibody were specific. Together, these results strongly suggest that TRPC3 channels are the effector channel of $D_{1}-D_{5}$ receptor coactivation in SNr GABA neurons such that an inhibition of TRPC 3 channels leads to an inhibition of $\mathrm{D}_{1}$-like excitation.

The next question was: how does $\mathrm{D}_{1}-\mathrm{D}_{5}$ receptor coactivation lead to enhanced TRPC3 channel activity? TRPC3 channels are known to be stimulated by lipid-mediated signaling mechanisms (Clapham, 2003; Albert and Large, 2006; Hardie, 2007; Venkatachalam and Montell, 2007; Nilius et al., 2008). Whereas $D_{1}$ and $D_{5}$ receptors are known to use the classical $G_{s}-$ or $G_{\text {Olf }}-$ cAMP signaling pathway (Neve et al., 2004), $\mathrm{D}_{1}-\mathrm{D}_{5}$ coactivation may stimulate $\mathrm{G}_{\mathrm{q} / 11}$ and phospholipase C (PLC), thereby triggering lipid signaling mechanisms (Rashid et al., 2007). If these lipid signaling mechanisms are involved, then inhibition of PLC should inhibit the DA response. Indeed, in SNr GABA neurons from slices incubated with a PLC inhibitor U73122 (1-[6[[(17ß)3-methoxyestra-1,3,5(10)-trien-17-yl]amino]hexyl]-1 $H$-pyrrole2,5-dione) $(5 \mu \mathrm{M})$ (Horowitz et al., 2005), $30 \mu \mathrm{M} \mathrm{DA}$ induced a depolarization of $0.5 \pm 0.1 \mathrm{mV}$ from their resting potential at approximately $-50 \mathrm{mV}$ in the presence of $1 \mu \mathrm{M}$ TTX $(n=9)$ (Fig. $7 A, C$ ). In contrast, in SNr GABA neurons from slices incubated with an adenylyl cyclase inhibitor $2^{\prime}, 5^{\prime}$-dd-3'AMP-bis(t-Bu-SATE) (5 $\mu \mathrm{M})$ (Laux et al., 2004), $30 \mu \mathrm{M}$ DA induced a depolarization of $2.6 \pm 0.3 \mathrm{mV}(n=8)$ from their resting potential at approximately $-50 \mathrm{mV}$ in the presence of 1 $\mu \mathrm{M}$ TTX (Fig. $7 B, C$ ). Under control condition, in SNr GABA neurons, $30 \mu \mathrm{M} \mathrm{DA}$ induced a depolarization of $2.8 \pm 0.2 \mathrm{mV}$ from their resting potential at approximately $-50 \mathrm{mV}$ in the 

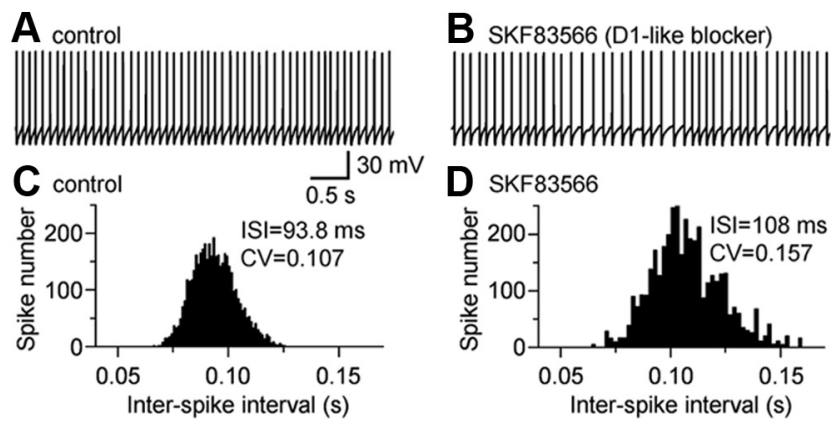

Figure 8. $\quad D_{1}$-like receptor blockade increased SNr GABA neuron firing irregularity. $A$, Spontaneous spikes recorded in an $\mathrm{SNr}$ GABA neuron under control conditions. $\boldsymbol{B}$, During exposure to $D_{1}$-like blocker SKF83566 $(5 \mu \mathrm{M})$, spiking became slower in frequency and more irregular in interval. C, Control ISI distribution was narrow and smooth. D, Distribution of ISI under SKF83566 became wider and more variable. Mean ISI and its CV are listed in the graphs.

presence of $1 \mu \mathrm{M}$ TTX $(n=13)$ (Fig. $7 C$ ) (see also Fig. 2C). Thus, inhibition of PLC, but not adenylyl cyclase, caused a substantial inhibition of the DA response.

$D_{1}$-like receptor blockade decreased $\mathrm{SNr}$ GABA neuron firing frequency and increased their firing irregularity: evidence for tonic $D_{1}-D_{5}$ receptor activity

Thus far, our data demonstrated unambiguously that exogenously applied DA- or selective $\mathrm{D}_{1}$-like agonists induced $\mathrm{D}_{1}$-like excitation in SNr GABA neurons. Now we turn to this critical question: can endogenous DA released from DA dendrites induce a similar $\mathrm{D}_{1}$-like excitation? Data addressing this question were already shown in Figures 4 and 5 and also in supplemental Figure S2 (available at www.jneurosci.org as supplemental material) and will be discussed in combination with additional data.

We hypothesized that spontaneously released DA from DA neuron dendrites may induce a tonic activation of $\mathrm{D}_{1}$ and $\mathrm{D}_{5}$ receptors and exert a tonic influence on $\mathrm{SNr}$ GABA neurons. Consequently, blocking these $\mathrm{D}_{1}$ and $\mathrm{D}_{5}$ receptors may reveal this potential tonic excitation. To test this idea, we first blocked fast GABA- and glutamate-mediated synaptic transmission with picrotoxin, D-AP-5, and CNQX. After establishing stable baseline recording, $5 \mu \mathrm{M}$ SKF83566 ( $\mathrm{D}_{1}$-like blocker) was bath applied to probe the potential tonic $\mathrm{D}_{1} / \mathrm{D}_{5}$ receptor activity. Indeed, SKF83566 significantly decreased SNr GABA neuron firing frequency by $8.6 \pm 1.7 \%$ (from $10.8 \pm 0.9 \mathrm{~Hz}$ under control conditions to $9.8 \pm 0.7 \mathrm{~Hz}$ during antagonist application; $n=10$; $p<0.01$ ) (Fig. $8 A-D$ ) (see also Fig. $4 B$ ). These results suggest that there is indeed a tonic $\mathrm{D}_{1}$-like receptor activity that normally increases SNr GABA neuron firing rate.

After blocking action potentials with $1 \mu \mathrm{M}$ TTX and obtaining stable membrane potential, bath application of $5 \mu \mathrm{M}$ SKF83566 induced a clear hyperpolarization of $0.7 \pm 0.2 \mathrm{mV}(n=9)$ in $\mathrm{SNr}$ GABA neurons (Fig. 4C). When the neurons were voltage clamped at $-70 \mathrm{mV}$, bath application of $5 \mu \mathrm{M}$ SKF83566 induced a clear outward current $(8.4 \pm 1.3 \mathrm{pA} ; n=8$ ) (Fig. $4 D)$ (supplemental Fig. S2, available at www.jneurosci.org as supplemental material). Whole-cell conductance was also decreased from $5.08 \pm 0.37 \mathrm{nS}$ under control condition to $4.72 \pm 0.35 \mathrm{nS}$ during SKF83566 application $(n=4)$. These effects were not seen in $\mathrm{SNr}$ GABA neurons in $\mathrm{D}_{1} \mathrm{KO}$ mice $(n=2)$ and $\mathrm{D}_{5} \mathrm{KO}$ mice $(n=2)$. Intracellular infusion of $\mathrm{D}_{1}$ or $\mathrm{D}_{5}$ receptor antibody also revealed a tonic $\mathrm{D}_{1}$ and $\mathrm{D}_{5}$ receptor-dependent excitation (Fig. $5 \mathrm{C}-\mathrm{H}$ ). These data clearly indicate that, in SNr GABA neurons, inhibition of $\mathrm{D}_{1}$ and $\mathrm{D}_{5}$ receptors induced an outward current, most likely by downregulating the tonically active TRPC3 channels.

The SNr GABA projection neuron firing pattern is often altered in Parkinson's disease (Wichmann et al., 1999; Tang et al., 2005). Therefore, a question arises: can $D_{1}$ and $D_{5}$ receptor activation in $\mathrm{SNr}$ GABA projection neurons contribute to the regulation of the firing pattern in these neurons? If it does, then DA neuron degeneration will likely lead to degradation of this regulation, potentially contributing to the symptoms of Parkinson's disease. We noticed that, during SKF83566 exposure, the decrease in $\mathrm{SNr}$ GABA neuron firing frequency or the increase in interspike interval (ISI) was accompanied by an increase in the irregularity of ISI. To quantify this change, the coefficient of variation (CV) of ISI under control and during SKF83566 was calculated. CV was computed by dividing the SD of ISI by the mean ISI (Bennett and Wilson, 1999; Lee et al., 2007; Zhou et al., 2008). Indeed, bath application of $5 \mu \mathrm{M}$ SKF83566 increased the CV of ISI by $27.5 \pm 4.5 \%(p<0.05 ; n=8)$ (Fig. $8 C, D)$. These results indicated that tonic activation of $\mathrm{D}_{1}$ and $\mathrm{D}_{5}$ receptors arising from endogenous DA release may help keep SNr GABA neurons sufficiently depolarized and spiking reliably at a regular interval.

\section{Additional evidence for DA neurons directly influencing $\mathrm{SNr}$ GABA neurons}

To provide more evidence for our hypothesis that SNc DA neurons can directly affect SNr GABA neurons, we did the following three additional sets of experiments.

In the first set of experiments, we stimulated SNc DA neurons and monitored responses in SNr GABA neurons. To evoke the maximal somatodendritic DA release and hence the maximal DA response, we adopted the published methods of burst-stimulating DA neurons (Chen and Rice, 2001; John et al., 2006). Each stimulation consisted of a burst of $1050-\mathrm{Hz}$ pulses delivered at every 5 min that prevents DA release depletion (Chen and Rice, 2001; John et al., 2006). Each pulse was $0.1 \mathrm{~ms}$ at $80-120 \mu \mathrm{A}$. The bipolar stimulating electrode was placed in the SNc. The recorded SNr GABA neurons were voltage clamped at $-80 \mathrm{mV}$ to increase driving force and prevent spontaneous spikes. The bathing solution was a blocking mixture (for details, see the legend of Fig. 9A). Under these conditions, burst stimulation of DA neurons induced a postsynaptic-like response in SNr GABA neurons. The peak amplitude was $7.1 \pm 0.8 \mathrm{pA}(n=4)$ (Fig. 9A). The rise time was $\sim 0.5 \mathrm{~s}$ and the decay time was $\sim 8 \mathrm{~s}$, although the small amplitude and consequently the interference from noise prevented precise measurement of these two parameters. This postsynaptic-like inward current was blocked by $2 \mu \mathrm{M} \mathrm{D}_{1}$-like antagonist SKF83566 (Fig. 9A), indicating that somatodendritically released DA may activate $\mathrm{D}_{1}$-like receptors in SNr GABA neurons. In contrast, endogenous DA induced a postsynapticlike, G-protein-gated inwardly rectifying $\mathrm{K}^{+}$channel-mediated, outward current in DA neurons by activating $\mathrm{D}_{2}$-like receptors in DA neurons (Beckstead et al., 2004).

In the second set of experiments, we examined the effects of $\mathrm{D}_{2}$-like agonist quinpirole that is known to inhibit DA neuron firing and presynaptic DA release via $\mathrm{D}_{2}$ autoinhibition (Lacey et al., 1987; Cragg and Greenfield, 1997; Pothos et al., 1998). We found that quinpirole $(1 \mu \mathrm{M})$ inhibited SNr GABA neuron firing rate by $5.9 \pm 1.0 \%(n=11)$ (Fig. $9 B)$. K-S tests on the distributions of firing rates in individual $\mathrm{SNr}$ GABA neurons indicate that the inhibition was significant $(p<0.05)$. We also tested the effects of $\mathrm{D}_{2}$-like antagonist sulpiride that is known to increase DA neuron firing and presynaptic DA release (Pucak and Grace, 1994; Cragg and Greenfield, 1997). We found that sulpiride 
$(1 \mu \mathrm{M})$ increased SNr GABA neuron firing rate by $6.2 \pm 1.1 \%(n=10 ; p<0.05)$ (Fig. 9B).

In the third set of experiments, we bath applied a DA uptake inhibitor GBR12909 (1[2-[bis(4-fluorophenyl)-methoxy] ethyl]-4[3-phenylpropyl]piperazine) that is known to increase the extracellular DA level (Rice and Cragg, 2008). To prevent the complication of DA-induced autoinhibition, 1 $\mu \mathrm{M}$ sulpiride was applied first before GBR12909. As shown in Figure 9B, $2 \mu \mathrm{M}$ GBR12909 increased the firing rate of $\mathrm{SNr}$ GABA neurons by $19.3 \pm 2.4 \%$ above drug-free control and $13.2 \pm 1.5 \%$ above that during $1 \mu \mathrm{M}$ sulpiride alone $(n=7$; $p<0.01)$

In the presence of $1 \mu \mathrm{M}$ TTX, in $\mathrm{SNr}$ GABA neurons, $D_{2}$-like agonist quinpirole $(1 \mu \mathrm{M})$ induced a $-0.4 \pm 0.0 \mathrm{mV}$ hyperpolarization $(n=3)$ (Fig. 9C), whereas $\mathrm{D}_{2}$-like antagonist sulpiride (1 $\mu \mathrm{M})$ induced a $0.5 \pm 0.1 \mathrm{mV}$ depolarization $(n=4)$ (Fig. 9C). DAT inhibitor GBR12909 $(2 \mu \mathrm{M})$ together with sulpiride $(1 \mu \mathrm{M})$ induced a $1.3 \pm 0.1 \mathrm{mV}$ depolarization over the drug-free baseline $(n=4)$ (Fig. 9C). In the presence of $\mathrm{D}_{1}$-like blocker SKF83566 (5 $\mu \mathrm{M})$, none of the effects of quinpirole and sulpiride described above was seen. GBR12909-induced depolarization was also blocked by $\mathrm{D}_{1}$-like antagonist SKF83566 (Fig. 9D), suggesting that $D_{1}$-like receptors were the common signaling pathway mediating the effects induced by $\mathrm{D}_{2}$-like ligands and DAT inhibitor GBR12909.

These results indicate that manipulation of DA neuron activity and DA release can affect SNr GABA neuron activity. The relatively weak effects are consistent with the established fact that DA neuron dendrites have $\mathrm{Na}^{+}$-spike-independent, pace-making activity-driven, L-type $\mathrm{Ca}^{2+}$ channel-mediated $\mathrm{Ca}^{2+}$ oscillation (Chan et al., 2007) that may be essential for the dendritic DA release. Certainly, $\mathrm{Ca}^{2+}$ release from internal stores may also contribute (Patel et al., 2009). Another factor is that the responses were recorded in 300- $\mu \mathrm{m}$-thick brain slices in which substantial numbers of DA neurons and GABA neurons and their dendrites were killed or injured during the tissue sectioning procedure, leading to a reduced magnitude of the endogenous DAmediated interactions. Thus, the endogenous DA-mediated interactions in intact animals are likely to be substantially larger.

\section{Discussion}

Based on a series of experiments using multiple different approaches, the major finding of this study is that nigral DA neurons form a novel ultra-short $\mathrm{SNc} \rightarrow \mathrm{SNr}$ DA pathway, in addition to the established long-distance nigro-striato-nigral loop (Fig. 9). In this ultra-short DA pathway, dendritically released DA exerts direct excitatory effects on SNr GABA projection neurons by an apparent coactivation of $D_{1}$ and $D_{5}$ receptors that subsequently enhances constitutively active TRPC3 channels in these neurons, leading to enhanced and more regular basal ganglia output.

\section{Dendritically released dopamine induces tonic $D_{1}$ and $D_{5}$ receptor activity in $\mathrm{SNr}$ GABA neurons}

SNr GABA projection neurons intermingle with DA dendrites that release DA (Björklund and Lindvall, 1975, Geffen et al., 1976; Cheramy et al., 1981; Cragg et al., 2001; Falkenburger et al., 2001). Endogenously released DA has been suggested to activate $\mathrm{D}_{1}$-like receptors on GABA and glutamate afferent terminals in the nigral areas and, hence, facilitate GABA and glutamate release (Cameron and Williams, 1993; Ibañez-Sandoval et al., 2006). Cheramy et al. (1981) also indicated that DA may directly affect $\mathrm{SNr}$ GABA projection neurons. Iontophoretic studies on DA effects on SNr GABA neurons in intact animals have produced conflicting results. For example, early studies (Ruffieux and Schultz, 1980; Waszcak and Walters, 1983) found that DA exerted an excitatory effect on SNr neurons, whereas a recent study (Windels and Kiyatkin, 2006) reported that DA had no consistent effects. 
Another recent study (Kliem et al., 2007) indicated that local infusion of a $\mathrm{D}_{1}$-like agonist generally reduced $\mathrm{SNr}$ GABA neuron firing rate via presynaptic mechanisms. However, these studies used extracellular recordings and consequently could not conclusively determine whether the effects were a direct excitation in SNr GABA neurons or were local circuit-mediated effects. These studies might also have been complicated by the fact that DA may affect multiple, potentially opposing synaptic inputs (such as glutamate and GABA) that may mask each other's effects on $\mathrm{SNr}$ GABA neuron firing.

To ensure that the observed responses were direct effects in the recorded SNr GABA neurons, our present study was performed after blocking these fast glutamate and GABA synaptic inputs. Under this isolated condition, we found that DA or $\mathrm{D}_{1}$-like agonists (SKF81297 and dihydrexidine) induced similar $\mathrm{D}_{1}$-like excitatory effects (depolarization or inward current accompanied by increased whole-cell conductance) in SNr GABA neurons. All these effects were prevented by a $D_{1}$-like receptor antagonist SKF83566. These effects were also absent in $D_{1} K O$ mice and $D_{5}$ $\mathrm{KO}$ mice and inhibited by intracellular application of $\mathrm{D}_{1}$ or $\mathrm{D}_{5}$ antibody. These results plus the data that SNr GABA neurons express both $\mathrm{D}_{1}$ and $\mathrm{D}_{5}$ mRNAs lead to the compelling conclusion that coactivation of $\mathrm{D}_{1}$ and $\mathrm{D}_{5}$ receptors induces a direct excitation in these basal ganglia output neurons.

In the present study, we also found that, after blocking fast GABA and glutamate receptors, $\mathrm{D}_{1}$-like antagonist SKF83566 induced a hyperpolarization in SNr GABA neurons and decreased their firing frequency accompanied by an increase in firing irregularity. These effects were absent in $\mathrm{D}_{1} \mathrm{KO}$ mice and also in $\mathrm{D}_{5}$ $\mathrm{KO}$ mice, strongly suggesting that spontaneously released DA may induce a tonic coactivation of $\mathrm{D}_{1}$ and $\mathrm{D}_{5}$ receptors that influences SNr GABA neuron activity. Direct stimulation of DA neurons induced a direct inward current in SNr GABA neurons that was sensitive to $D_{1}$-like blockade. Furthermore, manipulation of DA neuron activity and DA release with $\mathrm{D}_{2}$-like receptor ligands, and blockade of DA reuptake in particular, affected $\mathrm{SNr}$ GABA neuron firing. These data provide additional evidence that SNc DA neurons can directly influence SNr GABA neurons.

SNr GABA neurons may also feedback onto SNc DA neurons, as indicated by $\mathrm{D}_{1}$-like agonist SKF81297-induced increase in spontaneous IPSCs (sIPSCs) in DA neurons (supplemental Fig. S3, available at www.jneurosci.org as supplemental material). This result is consistent with our data that SKF81297 increased SNr GABA neuron firing, although the sIPSCs in DA neurons might have originated in SNr GABA neurons and also other GABA afferents (Tepper et al., 1995; Mailly et al., 2003; Misgeld, 2004).

\section{$D_{1}-D_{5}$ receptor coactivation enhances TRPC3 channel activity in SNr GABA neurons}

Our scRT-PCR consistently detected both $\mathrm{D}_{1}$ and $\mathrm{D}_{5}$ receptor mRNAs in SNr GABA neurons, although previous studies detected $D_{1}$ receptors only on striatonigral axon terminals but not in SNr GABA neurons (Mansour et al., 1992; Levey et al., 1993; Ariano, 1997). $\mathrm{D}_{5}$ receptor expression in $\mathrm{SNr}$ was implied, although the cell type(s) expressing this receptor was not known (Choi et al., 1995; Khan et al., 2000). The use of the highly sensitive and specific scRT-PCR techniques in the present study may explain this difference in detection.

$\mathrm{D}_{1}$ and $\mathrm{D}_{2}$ receptor coactivation and the underlying molecular mechanisms are relatively well established (Hopf et al., 2003; Rashid et al., 2007). Our functional demonstration of the requirement of both $D_{1}$ and $D_{5}$ receptors or coactivation of $D_{1}$ and $D_{5}$

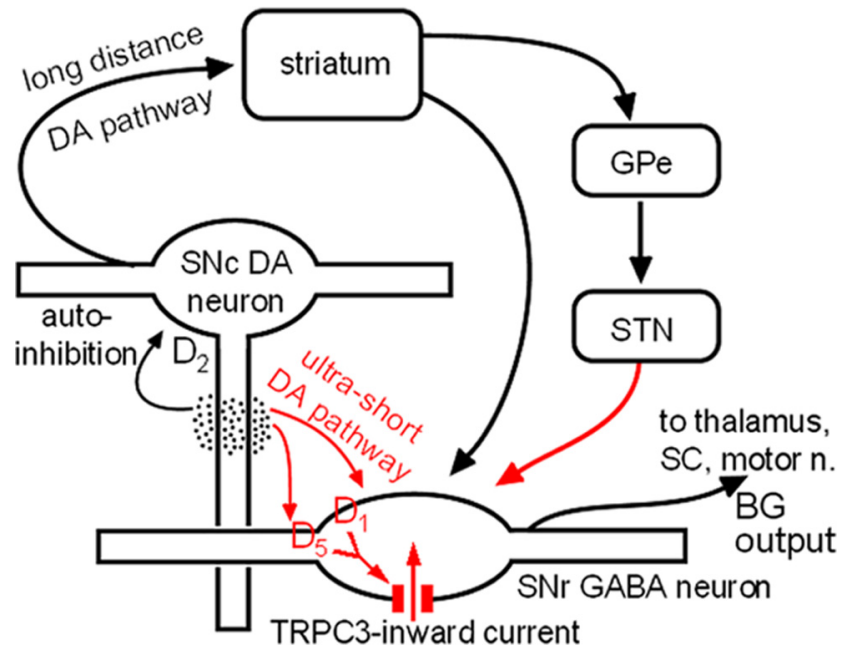

Figure 10. Diagrammatic representation of the novel ultra-short SNc $\rightarrow$ SNr DA pathway identified and characterized by our present study. DA dendrites are known to release DA and induce $D_{2}$-mediated autoinhibition in DA neurons. There is also the established long-distance nigro-striato-nigral loop. We have demonstrated that SNr GABA neurons express $D_{1}$ and $D_{5}$ receptors that ultimately couple to tonically active TRPC3 channels. Dendritically released DA also directly acts on SNr GABA output neurons, forming an ultra-short DA pathway that contributes to the regulation of the firing frequency and pattern of these basal ganglia output neurons. GPe, Globus pallidus external part; motor N, brainstem motor nuclei; BG, basal ganglia; STN, subthalamic nucleus; SC, superior colliculus.

receptors for the $\mathrm{D}_{1}$-like excitation is a novel finding. Despite a lack of direct molecular evidence, a recent review (Rashid et al., 2007 ) implied a $D_{1}-D_{5}$ receptor coactivation that can stimulate $\mathrm{G}_{\mathrm{q} / 11}$ activation and lipid signaling mechanism. Our present study provides the first data supporting this implied novel signaling pathway associated with these DA receptors. The apparent $D_{1}$ and $D_{5}$ receptor coactivation we observed may arise from receptor dimerization and/or downstream signaling mechanisms. Future studies are needed to elucidate the molecular mechanisms underlying this apparent $D_{1}$ and $D_{5}$ receptor coactivation.

Because $D_{1}$ and $D_{5}$ receptors do not directly gate any ion channel, to what ion channel does this $\mathrm{D}_{1}-\mathrm{D}_{5}$ coactivation couple? Our results show that the biophysical characteristics of the DA-induced inward current are almost identical to those of TRPC3 channel-mediated current: both are linear and voltage independent with reversal potential at approximately $-37 \mathrm{mV}$ (Fig. 3) (Zhou et al., 2008). Furthermore, intracellular application of TRPC3 channel antibody inhibited the $\mathrm{D}_{1}$-like effect in SNr GABA neurons (Fig. 6). These results strongly suggest that the $D_{1}-D_{5}$ receptor coactivation may ultimately couple to and enhance the constitutively active TRPC3 channels (Fig. 6A) that in turn regulate $\mathrm{SNr}$ GABA neurons. A DA regulation of TRPC3 channel activity is entirely possible because $\mathrm{D}_{1}-\mathrm{D}_{5}$ coactivation may activate $\mathrm{G}_{\mathrm{q} / 11}$ and phospholipase $\mathrm{C}$, thereby triggering lipids-mediated signaling mechanisms (Rashid et al., 2007) that are known to stimulate TRPC3 channels (Clapham, 2003; Hardie, 2007; Nilius et al., 2008).

\section{Functional implications}

Based primarily on the fact that DA dendrites may release DA in SNr, Cheramy et al. (1981) suggested that DA may directly affect SNr GABA projection neurons. Two pioneering studies indicated that iontophoretically applied DA exerts an excitatory effect on SNr neuron firing in intact animals (Ruffieux and Schultz, 1980; Waszcak and Walters, 1983). However, these studies used ex- 
tracellular recordings, did not remove synaptic inputs, and consequently could not determine whether the effect was a direct excitation in $\mathrm{SNr}$ neurons or local circuit-mediated effect. Because of technical limitations at these early dates, these studies also could not determine the DA receptor subtype(s) responsible for the effect. Two recent studies revisited this topic but led to conflicting conclusions on DA regulation of SNr GABA neurons (Windels and Kiyatkin, 2006; Kliem et al., 2007). Our present results are consistent with those of the two early in vivo studies (Ruffieux and Schultz, 1980; Waszcak and Walters, 1983). More importantly, our data provide cellular and molecular mechanisms for these early in vivo observations.

The nigral DA neurons are commonly described to regulate basal ganglia output through the long distance nigro-striatonigral pathway (Parent et al., 2000; Haber, 2003). However, DA dendrites and SNr GABA neurons intermingle with each other. As illustrated in Figure 10, our study shows that there is also an ultra-short $\mathrm{SNc} \rightarrow \mathrm{SNr}$ DA pathway that directly regulates $\mathrm{SNr}$ GABA neuron output. Besides the well known $\mathrm{D}_{2}$ receptormediated autoinhibition of nigral DA neurons, our data indicate that dendritically released $\mathrm{DA}$ induces a tonic $\mathrm{D}_{1}$ and $\mathrm{D}_{5}$ receptor coactivation-mediated hetero-excitation in SNr GABA projection neurons. This $\mathrm{D}_{1}$ and $\mathrm{D}_{5}$ receptor coactivation couples to and enhances tonically active TRPC3 channels, leading to the depolarized membrane potential, high firing rate, and regular firing pattern in SNr GABA projection neurons. Loss of DA neurons in Parkinson's disease may impair this novel ultra-short DA pathway, contributing to the complex neuropathophysiology and, hence, movement deficits. Indeed, a recent study found movement control deficits in TRPC3 channel knock-out mice (Hartmann et al., 2008). Although loss of TRPC3 channel in the cerebellum may be primarily responsible for the motor deficits, TRPC3 channel loss in SNr may also be involved.

\section{References}

Albert AP, Large WA (2006) Signal transduction pathways and gating mechanisms of native TRP-like cation channels in vascular myocytes. J Physiol 570:45-51.

Albert AP, Pucovsky V, Prestwich SA, Large WA (2006) TRPC3 properties of a native constitutively active $\mathrm{Ca}^{2+}$-permeable cation channel in rabbit ear artery myocytes. J Physiol 571:361-369.

Amaral MD, Pozzo-Miller L (2007) TRPC3 channels are necessary for brain-derived neurotrophic factor to activate a nonselective cationic current and to induce dendritic spine formation. J Neurosci 27:5179-5189.

Aosaki T, Kiuchi K, Kawaguchi Y (1998) Dopamine $D_{1}$-like receptor activation excites rat striatal large aspiny neurons in vitro. J Neurosci 18:5180-5190.

Aragay AM, Collins LR, Post GR, Watson AJ, Feramisco JR, Brown JH, Simon MI (1995) $G_{12}$ requirement for thrombin-stimulated gene expression and DNA synthesis in $1321 \mathrm{~N} 1$ astrocytoma cells. J Biol Chem 270:20073-20077.

Ariano MA (1997) Distribution of dopamine receptors. In: The dopamine receptors (Neve KA, Neve RL, ed), pp 77-103. Totowa, NJ: Humana.

Atherton JF, Bevan MD (2005) Ionic mechanisms underlying autonomous action potential generation in the somata and dendrites of GABAergic substantia nigra pars reticulata neurons in vitro. J Neurosci $25: 8272-8281$.

Beckstead MJ, Grandy DK, Wickman K, Williams JT (2004) Vesicular dopamine release elicits an inhibitory postsynaptic current in midbrain dopamine neurons. Neuron 42:939-946.

Bennett BD, Wilson CJ (1999) Spontaneous activity of neostriatal cholinergic interneurons in vitro. J Neurosci 19:5586-5596.

Björklund A, Lindvall O (1975) Dopamine in dendrites of substantia nigra neurons: suggestions for a role in dendritic terminals. Brain Res 83:531-537.

Cameron DL, Williams JT (1993) Dopamine $\mathrm{D}_{1}$ receptors facilitate transmitter release. Nature 366:344-347.
Centonze D, Grande C, Usiello A, Gubellini P, Erbs E, Martin AB, Pisani A, Tognazzi N, Bernardi G, Moratalla R, Borrelli E, Calabresi P (2003) Receptor subtypes involved in the presynaptic and postsynaptic actions of dopamine on striatal interneurons. J Neurosci 23:6245-6254.

Chan CS, Guzman JN, Ilijic E, Mercer JN, Rick C, Tkatch T, Meredith GE, Surmeier DJ (2007) "Rejuvenation" protects neurons in mouse models of Parkinson's disease. Nature 447:1081-1086.

Chen BT, Rice ME (2001) Novel $\mathrm{Ca}^{2+}$ dependence and time course of somatodendritic dopamine release: substantia nigra versus striatum. J Neurosci 21:7841-7847.

Cheramy A, Leviel V, Glowinski J (1981) Dendritic release of dopamine in the substantia nigra. Nature 289:537-542.

Choi WS, Machida CA, Ronnekleiv OK (1995) Distribution of dopamine $D_{1}, D_{2}$, and $D_{5}$ receptor mRNAs in the monkey brain: ribonuclease protection assay analysis. Mol Brain Res 31:86-94.

Clapham DE (2003) TRP channels as cellular sensors. Nature 426:517-524.

Cragg SJ, Greenfield SA (1997) Differential autoreceptor control of somatodendritic and axon terminal dopamine release in substantia nigra, ventral tegmental area, and striatum. J Neurosci 17:5738-5746.

Cragg SJ, Nicholson C, Kume-Kick J, Tao L, Rice ME (2001) Dopaminemediated volume transmission in midbrain is regulated by distinct extracellular geometry and uptake. J Neurophysiol 85:1761-1771.

DeLong MR, Wichmann T (2007) Circuits and circuit disorders of the basal ganglia. Arch Neurol 64:20-24.

Falkenburger BH, Barstow KL, Mintz IM (2001) Dendrodendritic inhibition through reversal of dopamine transport. Science 293:2465-2470.

Fallon JH, Loughlin SE (1995) Substantia nigra. In: The rat nervous system (Paxinos G, ed), pp 215-237. San Diego: Academic.

Geffen LB, Jessell TM, Cuello AC, Iversen LL (1976) Release of dopamine from dendrites in rat substantia nigra. Nature 260:258-260.

González-Hernández T, Rodríguez M (2000) Compartmental organization and chemical profile of dopaminergic and GABAergic neurons in the substantia nigra of the rat. J Comp Neurol 421:107-135.

Haber SN (2003) The primate basal ganglia: parallel and integrative networks. J Chem Neuroanat 26:317-330.

Hardie RC (2007) TRP channels and lipids: from Drosophila to mammalian physiology. J Physiol 578:9-24.

Harris NC, Constanti A (1995) Mechanism of block by ZD 7288 of the hyperpolarization-activated inward rectifying current in guinea pig substantia nigra neurons in vitro. J Neurophysiol 74:2366-2378.

Hartmann J, Dragicevic E, Adelsberger H, Henning HA, Sumser M, Abramowitz J, Blum R, Dietrich A, Freichel M, Flockerzi V, Birnbaumer L, Konnerth A (2008) TRPC3 channels are required for synaptic transmission and motor coordination. Neuron 59:392-398.

Hikosaka O, Wurtz RH (1983) Visual and oculomotor functions of monkey substantia nigra pars reticulata. I. Relation of visual and auditory responses to saccades. J Neurophysiol 49:1230-1253.

Hikosaka O, Takikawa Y, Kawagoe R (2000) Role of the basal ganglia in the control of purposive saccadic eye movements. Physiol Rev 80:953-978.

Hollon TR, Bek MJ, Lachowicz JE, Ariano MA, Mezey E, Ramachandran R, Wersinger SR, Soares-da-Silva P, Liu ZF, Grinberg A, Drago J, Young WS 3rd, Westphal H, Jose PA, Sibley DR (2002) Mice lacking $D_{5}$ dopamine receptors have increased sympathetic tone and are hypertensive. J Neurosci 22:10801-10810.

Hopf FW, Cascini MG, Gordon AS, Diamond I, Bonci A (2003) Cooperative activation of dopamine $D_{1}$ and $D_{2}$ receptors increases spike firing of nucleus accumbens neurons via G-protein $\beta \gamma$ subunits. J Neurosci 23:5079-5087.

Horowitz LF, Hirdes W, Suh BC, Hilgemann DW, Mackie K, Hille B (2005) Phospholipase $\mathrm{C}$ in living cells: activation, inhibition, $\mathrm{Ca}^{2+}$ requirement, and regulation of M current. J Gen Physiol 126:243-262.

Ibañez-Sandoval O, Hernández A, Florán B, Galarraga E, Tapia D, Valdiosera R, Erlij D, Aceves J, Bargas J (2006) Control of the subthalamic innervation of substantia nigra pars reticulata by $\mathrm{D}_{1}$ and $\mathrm{D}_{2}$ dopamine receptors. J Neurophysiol 95:1800-1811.

Jaffe EH, Marty A, Schulte A, Chow RH (1998) Extrasynaptic vesicular transmitter release from the somata of substantia nigra neurons in rat midbrain slices. J Neurosci 18:3548-3553.

John CE, Budygin EA, Mateo Y, Jones SR (2006) Neurochemical characterization of the release and uptake of dopamine in ventral tegmental area and serotonin in substantia nigra of the mouse. J Neurochem 96:267-282. Khan ZU, Gutiérrez A, Martín R, Peñafiel A, Rivera A, de la Calle A (2000) 
Dopamine $\mathrm{D}_{5}$ receptors of rat and human brain. Neuroscience 100:689-699.

Kliem MA, Maidment NT, Ackerson LC, Chen S, Smith Y, Wichmann T (2007) Activation of nigral and pallidal dopamine D1-Like receptors modulates basal ganglia outflow in monkeys. J Neurophysiol 98:14891500 .

Lacey MG, Mercuri NB, North RA (1987) Dopamine acts on $\mathrm{D}_{2}$ receptors to increase potassium conductance in neurones of the rat substantia nigra zona compacta. J Physiol 392:397-416.

Laux WH, Pande P, Shoshani I, Gao J, Boudou-Vivet V, Gosselin G, Johnson RA (2004) Pro-nucleotide inhibitors of adenylyl cyclases in intact cells. J Biol Chem 279:13317-13332.

Lee CR, Tepper JM (2007) A calcium-activated nonselective cation conductance underlies the plateau potential in rat substantia nigra GABAergic neurons. J Neurosci 27:6531-6541.

Lee JI, Verhagen Metman L, Ohara S, Dougherty PM, Kim JH, Lenz FA (2007) Internal pallidal neuronal activity during mild drug-related dyskinesias in Parkinson's disease: decreased firing rates and altered firing patterns. J Neurophysiol 97:2627-2641.

Levey AI, Hersch SM, Rye DB, Sunahara RK, Niznik HB, Kitt CA, Price DL, Maggio R, Brann MR, Ciliax BJ (1993) Localization of $\mathrm{D}_{1}$ and $\mathrm{D}_{2}$ dopamine receptors in brain with subtype-specific antibodies. Proc Natl Acad Sci U S A 90:8861-8865.

Lovenberg TW, Brewster WK, Mottola DM, Lee RC, Riggs RM, Nichols DE, Lewis MH, Mailman RB (1989) Dihydrexidine, a novel selective high potency full dopamine D-1 receptor agonist. Eur J Pharmacol 166:111-113.

Mailly P, Charpier S, Menetrey A, Deniau JM (2003) Three-dimensional organization of the recurrent axon collateral network of the substantia nigra pars reticulata neurons in the rat. J Neurosci 23:5247-5257.

Mansour A, Meador-Woodruff JH, Zhou Q, Civelli O, Akil H, Watson SJ (1992) A comparison of $D_{1}$ receptor binding and mRNA in rat brain using receptor autoradiographic and in situ hybridization techniques. Neuroscience 46:959-971.

McHaffie JG, Stanford TR, Stein BE, Coizet V, Redgrave P (2005) Subcortical loops through the basal ganglia. Trends Neurosci 28:401-407.

Mercuri NB, Saiardi A, Bonci A, Picetti R, Calabresi P, Bernardi G, Borrelli E (1997) Loss of autoreceptor function in dopaminergic neurons from dopamine $\mathrm{D}_{2}$ receptor deficient mice. Neuroscience 79:323-327.

Misgeld U (2004) Innervation of the substantia nigra. Cell Tissue Res 318:107-114.

Nelson EL, Liang CL, Sinton CM, German DC (1996) Midbrain dopaminergic neurons in the mouse: computer-assisted mapping. J Comp Neurol 369:361-371.

Neve KA, Seamans JK, Trantham-Davidson H (2004) Dopamine receptor signaling. J Recept Signal Transduct Res 24:165-205.

Nevet A, Morris G, Saban G, Fainstein N, Bergman H (2004) Discharge rate of substantia nigra pars reticulata neurons is reduced in nonparkinsonian monkeys with apomorphine-induced orofacial dyskinesia. J Neurophysiol 92:1973-1981.

Nilius B, Owsianik G, Voets T (2008) Transient receptor potential channels meet phosphoinositides. EMBO J 27:2809-2816.

Obeso JA, Rodríguez-Oroz MC, Rodríguez M, Lanciego JL, Artieda J, Gonzalo N, Olanow CW (2000) Pathophysiology of the basal ganglia in Parkinson's disease. Trends Neurosci 23:S8-S19.

Parent A, Sato F, Wu Y, Gauthier J, Lévesque M, Parent M (2000) Organization of the basal ganglia: the importance of axonal collateralization. Trends Neurosci 23:S20-S27.

Patel JC, Witkovsky P, Avshalumov MV, Rice ME (2009) Mobilization of calcium from intracellular stores facilitates somatodendritic dopamine release. J Neurosci 29:6568-6579.

Pothos EN, Przedborski S, Davila V, Schmitz Y, Sulzer D (1998) D 2 -Like dopamine autoreceptor activation reduces quantal size in PC12 cells. J Neurosci 18:5575-5585.

Pucak ML, Grace AA (1994) Evidence that systemically administered dopamine antagonists activate dopamine neuron firing primarily by blockade of somatodendritic autoreceptors. J Pharmacol Exp Ther 271:1181-1192.

Rashid AJ, O’Dowd BF, Verma V, George SR (2007) Neuronal Gq/11coupled dopamine receptors: an uncharted role for dopamine. Trends Pharmacol Sci 28:551-555.

Rice ME, Cragg SJ (2008) Dopamine spillover after quantal release: rethinking dopamine transmission in the nigrostriatal pathway. Brain Res Rev 58:303-313.

Ruffieux A, Schultz W (1980) Dopaminergic activation of reticulata neurons in the substantia nigra. Nature 285:240-241.

Schultz W (1986) Activity of pars reticulata neurons of monkey substantia nigra in relation to motor, sensory, and complex events. J Neurophysiol 55:660-677.

Staal RG, Mosharov EV, Sulzer D (2004) Dopamine neurons release transmitter via a flickering fusion pore. Nat Neurosci 7:341-346.

Surmeier DJ, Song WJ, Yan Z (1996) Coordinated expression of dopamine receptors in neostriatal medium spiny neurons. J Neurosci 16:6579-6591.

Tang JK, Moro E, Lozano AM, Lang AE, Hutchison WD, Mahant N, Dostrovsky JO (2005) Firing rates of pallidal neurons are similar in Huntington's and Parkinson's disease patients. Exp Brain Res 66:230-236.

Tauc L (1980) Intraneuronal injection of enzymes. Trends Neurosci 3:241-245

Tepper JM, Martin LP, Anderson DR (1995) GABAA receptor-mediated inhibition of rat substantia nigra dopaminergic neurons by pars reticulata projection neurons. J Neurosci 15:3092-3103.

Venkatachalam K, Montell C (2007) TRP channels. Annu Rev Biochem 76:387-417.

Waszcak BL, Walters JR (1983) Dopamine modulation of the effects of $\gamma$-aminobutyric acid on substantia nigra pars reticulata neurons. Science 220:218-221.

Wichmann T, Bergman H, Starr PA, Subramanian T, Watts RL, DeLong MR (1999) Comparison of MPTP-induced changes in spontaneous neuronal discharge in the internal pallidal segment and in the substantia nigra pars reticulata in primates. Exp Brain Res 125:397-409.

Windels F, Kiyatkin EA (2006) Dopamine action in the substantia nigra pars reticulata: iontophoretic studies in awake, unrestrained rats. Eur J Neurosci 24:1385-1394.

Xu M, Moratalla R, Gold LH, Hiroi N, Koob GF, Graybiel AM, Tonegawa S (1994) Dopamine $\mathrm{D}_{1}$ receptor mutant mice are deficient in striatal expression of dynorphin and in dopamine-mediated behavioral responses. Cell 79:729-742.

Yasumoto S, Tanaka E, Hattori G, Maeda H, Higashi H (2002) Direct and indirect actions of dopamine on the membrane potential in medium spiny neurons of the mouse neostriatum. J Neurophysiol 87:1234-1243.

Zhao G, Adebiyi A, Blaskova E, Xi Q, Jaggar JH (2008) Type 1 inositol 1,4,5-trisphosphate receptors mediate UTP-induced cation currents, $\mathrm{Ca}^{2+}$ signals, and vasoconstriction in cerebral arteries. Am J Physiol Cell Physiol 295:C1376-C1384.

Zhou FW, Matta SG, Zhou FM (2008) Constitutively active TRPC3 channels regulate basal ganglia output neurons. J Neurosci 28:473-482.

Zhou FW, Xu JJ, Zhao Y, LeDoux MS, Zhou FM (2006) Opposite functions of histamine $\mathrm{H}_{1}$ and $\mathrm{H}_{2}$ receptors and $\mathrm{H}_{3}$ receptor in substantia nigra pars reticulata. J Neurophysiol 96:1581-1591. 